\title{
Geophysical Logging Case History of the Raft River Geothermal System, Idaho
}




\section{DISCLAIMER}

This report was prepared as an account of work sponsored by an agency of the United States Government. Neither the United States Government nor any agency Thereof, nor any of their employees, makes any warranty, express or implied, or assumes any legal liability or responsibility for the accuracy, completeness, or usefulness of any information, apparatus, product, or process disclosed, or represents that its use would not infringe privately owned rights. Reference herein to any specific commercial product, process, or service by trade name, trademark, manufacturer, or otherwise does not necessarily constitute or imply its endorsement, recommendation, or favoring by the United States Government or any agency thereof. The views and opinions of authors expressed herein do not necessarily state or reflect those of the United States Government or any agency thereof. 


\section{DISCLAIMER}

Portions of this document may be illegible in electronic image products. Images are produced from the best available original document. 
An Affirmative Action/Equal Opportunity Employer

This report was prepared is an account of work sponsored by the United States Government. Neither the United States nor the United States Department of Energy, nor any of their employees, makes any warranty, express or implied, or assumes any legal liability or responsibility for implied, or assumes any legal liability or responsibility for mation, apparatus, product, or process disclosed, or represents that its use would not infringe privately owned rights. Reference herein to any specific commercial product, process, or service by trade name, mark, manufacturer, or pross. or service 100 ute or imply its endorsement, recommendation, or favoring by the United States Government or any agency thereof. The views and opinions of authors expressed herein do not necessarily state or reflect those of the United States Government or any agency thereof.

UNITED STATES

DEPARTMENT OF ENERGY

CONTRACT W-7408-ENG. 36 
LA-8252-MS

Informal Report

UC-66a

Issued: April 1980

\title{
Geophysical Logging Case History of the Raft River Geothermal System, Idaho
}

\author{
Prepared for \\ Los Alamos Scientific Laboratory
}

by

James K. Applegate*

Tracy A. Moens*

*Boise State University, Geology Department, Boise, ID 83725.
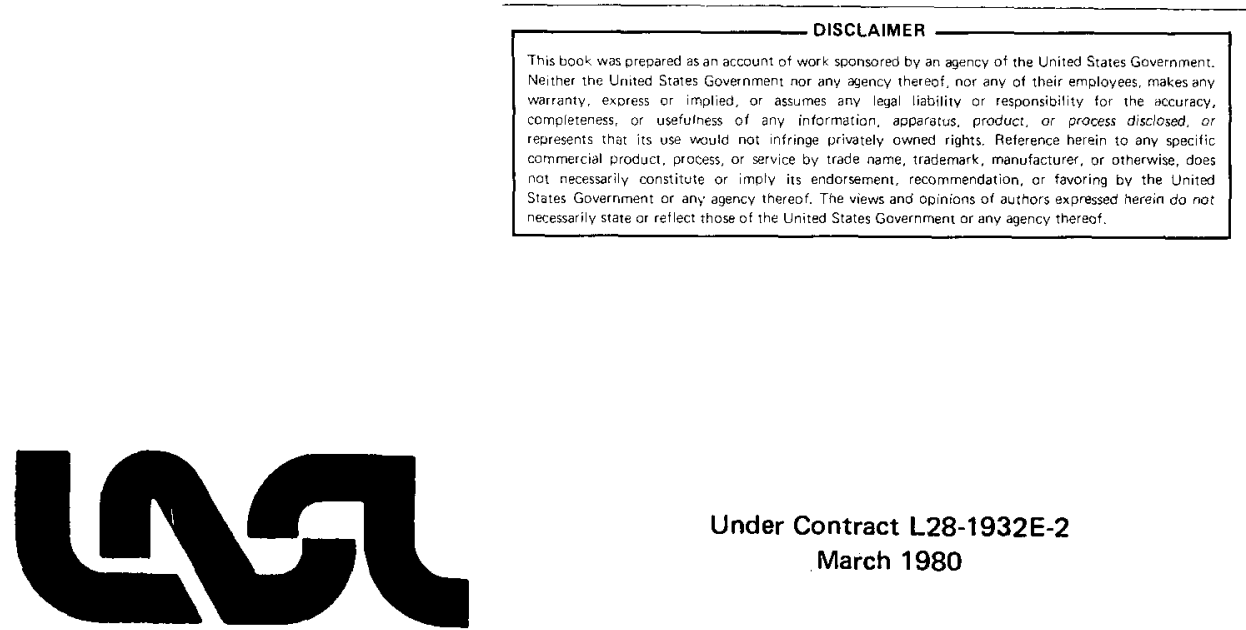
GEOPHYSICAL LOGGING CASE HISTORY OF THE

RAFT RIVER GEOTHERMAL SYSTEM, IDAHO

by

James K. Applegate and Tracy A. Moens

\begin{abstract}
Drilling to evaluate the geothermal resource in the Raft River Valley began in 1974 and resulted in the discovery of a geothermal reservoir at a depth of approximately $1523 \mathrm{~m}$ (5000 ft). Several organizations and companies have been involved in the geophysical logging program. There is no comprehensive report on the geophysical logging, nor has there been a complete interpretation. The objectives of this study are to make an integrated interpretation of the available data and compile a case history. Emphasis has been on developing a simple interpretation scheme from a minimum of data sets.

The Raft River geothermal system occurs in the Raft River Valley, which is a portion of the Basin and Range geomorphic province located in south central Idaho, south of the Snake River Plain. The valley is a late Cenozoic structural downwarp bounded by faults on the west, south, and east. The downwarp is filled with Tertiary and Paleozoic sediments, metasediments, and volcanics that overlie Precambrian rocks.

The variety of rock types, the presence of alteration products, and the variability of fracturing make reliable interpretations difficult. However, the cross plotting of various parameters has allowed a determination of rock types and an analysis of the degree of alteration and the density of fractures. Thus, one can determine the relevant data necessary to assess a geothermal reservoir in similar rock types and use cross plots to potentially define the producing zones.
\end{abstract}




\section{INTRODUCTION}

This study reviewed commercial geophysical logs that have been run in several geothermal holes drilled in the Raft River Valley, Idaho. Major objectives were to decide whether adequate logs were obtained, whether adequate quality control was maintained, whether the logs responded as normally anticipated, and last, whether the data were useful in the evaluation of the geothermal reservoir.

The Raft River Valley is in the Basin and Range Province, and is located in south central Idaho, south of the Snake River Plain, and north of the UtahIdaho state line (Fig. 1). For many years local residents in the valley have used hot water from springs and shallow wells for agricultural purposes, including greenhouses and other nonelectrical applications. In 1973, the study began under what is now the US Department of Energy (DOE) and the Raft River Electrical Cooperative. A study of the geothermal potential of the Raft

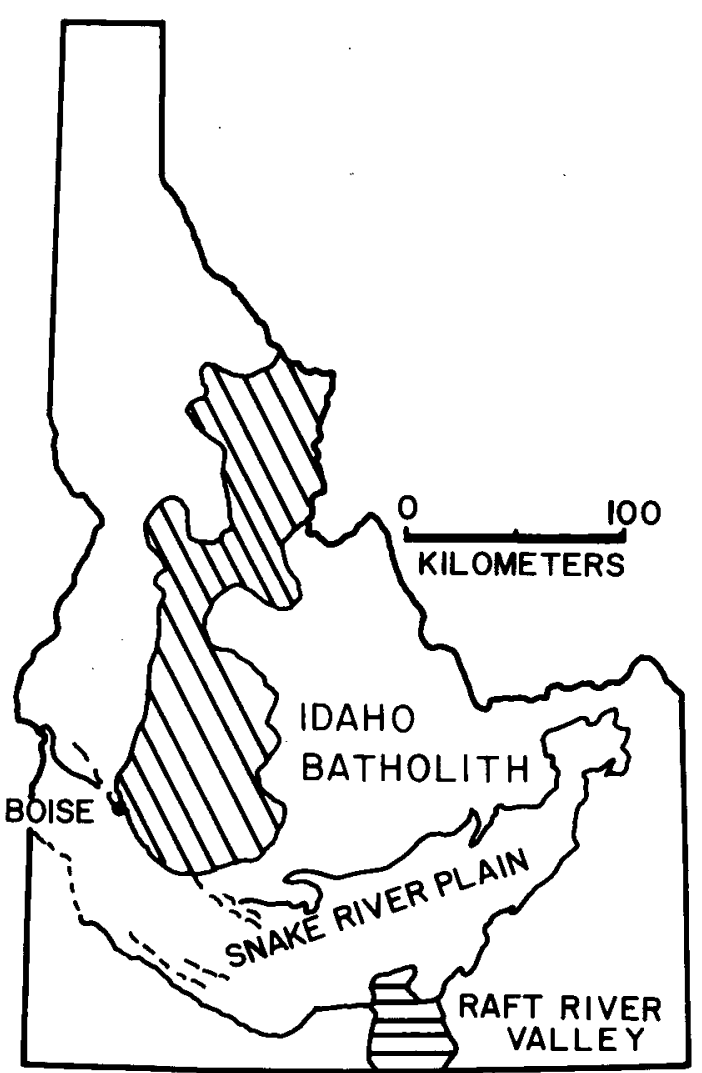

Fig. 1. Location of Raft River Valley with respect to the Snake River Plain and Idaho Batholith.
River Valley was begun to assess techniques for using low- to moderatetemperature hot water for power generation. Technology is available to generate power from high-temperature steam, but the water at the Raft River

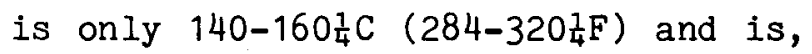
consequently, of marginal temperature for current technology for power generation. Thus the plan, as originally conceived, was to build a demonstration plant. The US Geological Survey (USGS) and several firms and organizations have also participated in the Raft River resource evaluation.

Exploratory drilling began in the area in 1974. To date, five deep exploration and/or production wells of approximately 1520-m (5000-ft) depth or deeper and two injection wells [slightly deeper than $1070 \mathrm{~m}$ 
(3500 ft)] have been drilled in the valley. In addition, numerous shallow wells have been drilled to monitor the ground-water system and to better understand the near-surface geology of the area.

The five exploration and/or production wells and the two injection wells were geophysically logged using commercial logging services. In addition, the USGS Division of Water Resources also logged these wells. The object of this report is to review the commercial $\log$ data and to make detailed analysis of the reservoir potential.

As a result of the geothermal investigations in the area, plans are progressing to build a demonstration plant. If full development is carried out, additional hot water production may be needed. Thus, the objective is to predict what log analysis techniques might work in similar geological environments, to aid in suggesting what types of logs should be run in future wells, and to determine potential locations for drilling other wells.

II. GEOLOGY

Many of workers have discussed the geology of the Raft River geothermal system. Mabey et al. (1975), Williams et al. (1975), Zohdy et al. (1975), Ackerman (1975), Nichols and Applegate (1974), Applegate and Donaldson (1977), Mabey et al. (1978), have all discussed the geology and geophysics.

The Raft River Valley is in the Basin and Range geomorphic province and several major structures are prominent in the valley. The valley is approximately $60 \mathrm{~km}(37 \mathrm{mi})$ NS and $25 \mathrm{~km}(15 \mathrm{mi}) \mathrm{EW}$. Two major structures are a major NE-trending zone, called the Narrows zone, and a NS-trending feature called the Bridge fault zone (Fig. 2). These features may have significant structural control on the geothermal system in the Raft River Valley.

The Raft River Valley is a late Cenozoic downwarp bounded by faulting on the west, south, and east (Williams et al., 1975). The downwarp is filled with a combination of Tertiary sediments and volcanics that overlie Paleozoic and Precambrian rocks. The Tertiary deposits are composed of Pleistocene and Holocene gravel, alluvium, silt, and sand, in addition to the tuffaceous sediments, volcanics, sediments, and conglomerates of the Pliocene Salt Lake Formation. Beneath these units are complex Paleozoics that include quartzite, schist, and other metamorphics that overlie Precambrian rocks, principally of quartz monzonite. The lower portion of the Tertiary section, the Paleozoic 


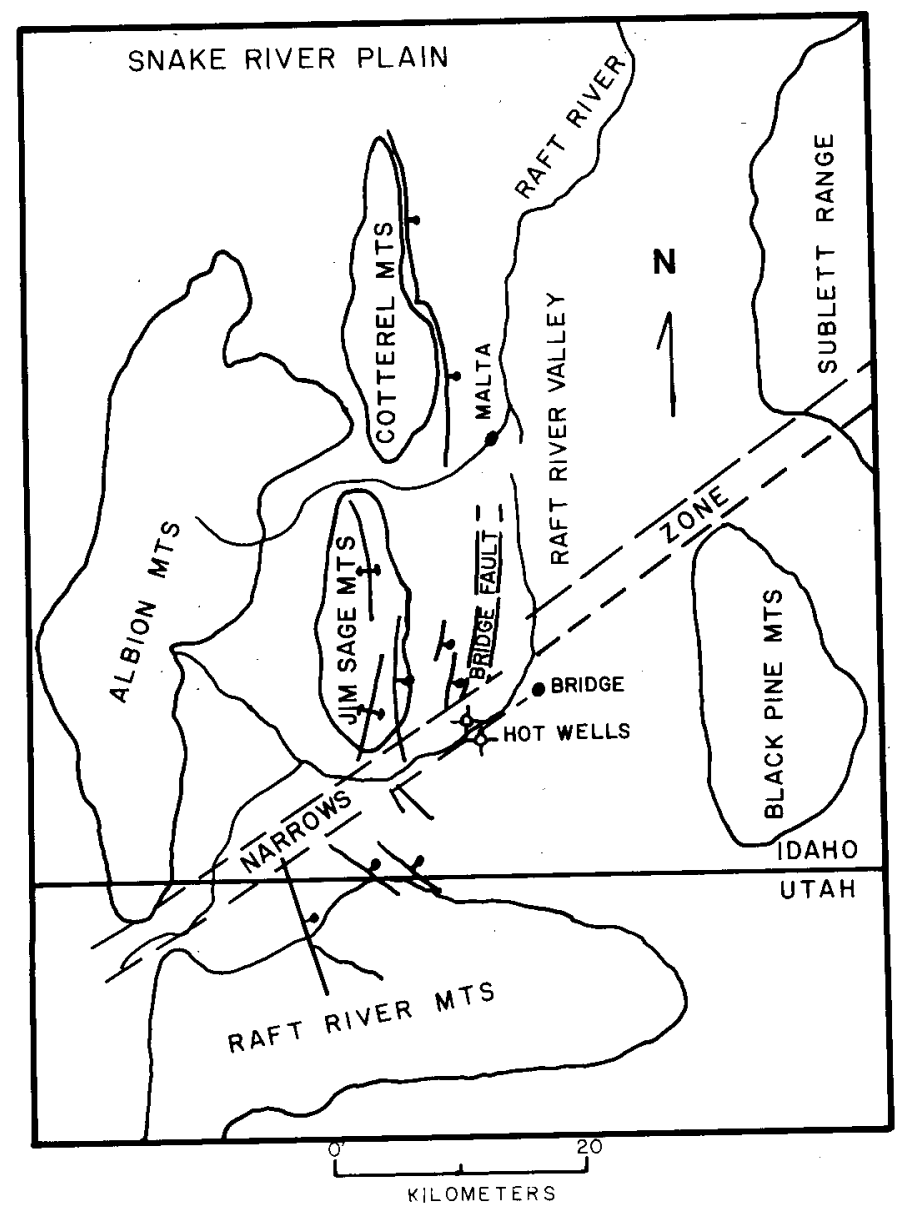

Fig. 2. Major structural elements in the Raft River Valley (modified from Mabey et al., 1978). metamorphics, and perhaps the Precambrian quartz monzonite, are of primary importance in the geothermal system.

III. SURFACE GEOPHYSICS

Extensive geophysical surveys were conducted in the area by the USGS and include gravity, magnetic, refraction seismic, resistivity, audiomagnetotelluric, self-potential, and telluric surveys (Corrington, 1977). These studies indicate the presence of approximately $2000 \mathrm{~m}$ ( $6500 \mathrm{ft}$ ) of Cenozoic sedimentary and volcanic rocks, which is in agreement with the general geological interpretation. Large-scale structural features as interpreted from LANDSAT imagery are clearly evident in the geophysical studies and consistent with geological interpretations.

IV. BOREHOLE DATA

Figure 3 shows the relative locations of the five deep wells and the two injection wells that have been drjlled. The deep wells were drilled to test both the Narrows and the Bridge structures. All five exploration/production wells were drilled to depths in excess of $1375 \mathrm{~m}$ (4500 ft). Injection wells were drilled to depths of more than $1075 \mathrm{~m}$ (3500 ft). This study is primarily concerned with the five exploration and production wells.

RRGE No. 1 was drilled to a depth of $1520 \mathrm{~m}$ (4988 ft). It is uncased

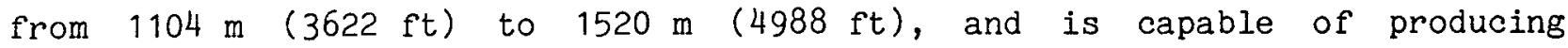
4739 l/min (1250 gal./min). 


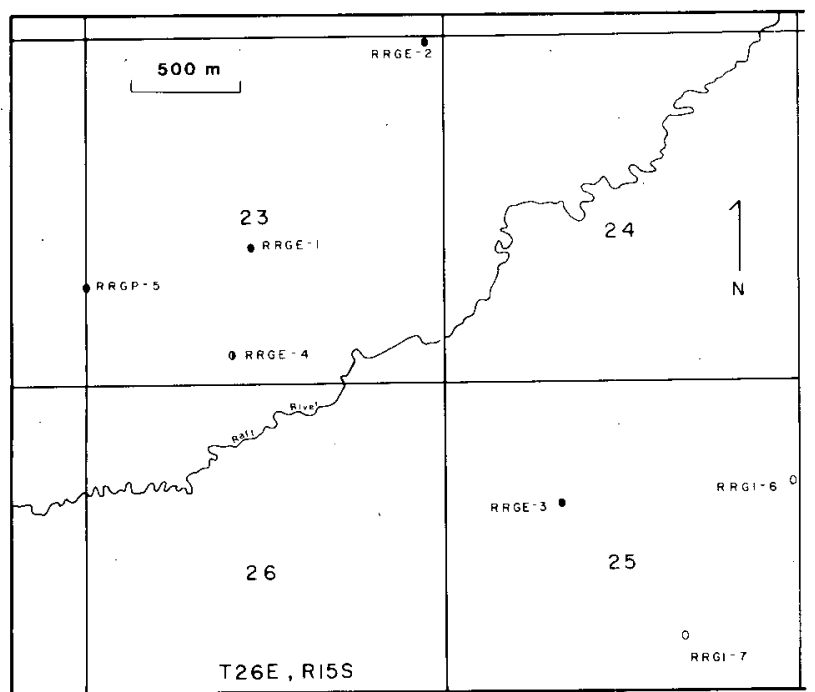

Fig. 3. Locations of wells drilled to date. Solid circles are producing wells, shaded half circles are very poor producers, and open circles are injection wells.

RRGE No. 2 was drilled to a depth of $1994 \mathrm{~m}(6543 \mathrm{ft})$ and is uncased below $1288 \mathrm{~m}$ (4227 ft). Extrapolations from test data and injection data coupled with temperature logging show that production occurs from small intervals at depths of about $1341 \mathrm{~m}(4400 \mathrm{ft}), 1585 \mathrm{~m}$ $(5200 \mathrm{ft})$, and $1829 \mathrm{~m}(6000 \mathrm{ft})$. This well is capable of producing $3032 \mathrm{l} / \mathrm{min}$ ( $800 \mathrm{gal} / \mathrm{min})$. RRGE No. 3 has three legs. Most of the production is from leg $C$. Legs $A$ and $B$ produce very little fluid. Leg $C$ is open between $1292 \mathrm{~m}$ (4240 ft) and $1804 \mathrm{~m}$ (5920 ft). RRGE No. 4 has two legs. They are open from approximately $1053 \mathrm{~m}$

$(3470 \mathrm{ft})$ to $1585 \mathrm{~m}(5200 \mathrm{ft})$. This well has very poor production--about $57 \mathrm{\ell} / \mathrm{min}$ (15 gal./min).

RRGE No. 5 is capable of producing $2464 \mathrm{l} / \mathrm{min}$ ( $650 \mathrm{gal} / \mathrm{min}$ ), and it is open from $1039 \mathrm{~m}$ (3408 ft) to $1504 \mathrm{~m}$ (4934 ft).

Fluid in these wells ranges in temperature from $133^{\circ} \mathrm{C}\left(272^{\circ} \mathrm{F}\right)$ to $147^{\circ} \mathrm{C}$ $\left(296^{\circ} \mathrm{F}\right)$. Most of the wells are around $138^{\circ} \mathrm{C}\left(280^{\circ} \mathrm{F}\right)$ temperature with RRGE No. 3 as the hottest and RRGE No. 5 as the coldest.

A relatively complete suite of logs was run in each well. The log suites vary slightly depending on the service company and the specific logging program. The basic suite included the following logs: temperature, one-arm caliper, acoustic, electrical, neutron, and density. Additional logs were run in a few wells, including the spectral gamma and fracture logs and the dip and flow meters. The logs were intended to be recorded in analog and digital forms for ease in data processing.

At. the initiation of this study, it was reported that the log data had all been digitized except for the data from RRGE No. 1 and No. 2. Consequently, for this study, funding was received to digitize a portion of the commercial geophysical logs from RRGE No. 1 and No. 2. Unfortunately, it was 
discovered that none of the other data were digitized. There was not sufficient funding to digitize the other logs so this study was restricted to that small quantity of data. Therefore, our analysis must be based on comercially digitized portions of RRGE No. 1 and No. 2 and a small hand-digitized sample of RRGE No. 4. RRGE Nos. 1 and 2 with good production are compared with very poor production from RRGE No. 4.

Water was the drilling fluid for all the wells. Consequently, there are severe problems with borehole size. The one-arm caliper log recorded a significant amount of the time at full scale and thus, correct borehole size was not measured. Borehole size correction cannot be made to the other log data when this occurs. Figure 4 shows some of the data from the zone of interest in RRGE No. 2. Some of the major lithologic changes can be seen on the raw $\log s$, but it is difficult to define detailed zones of interest.

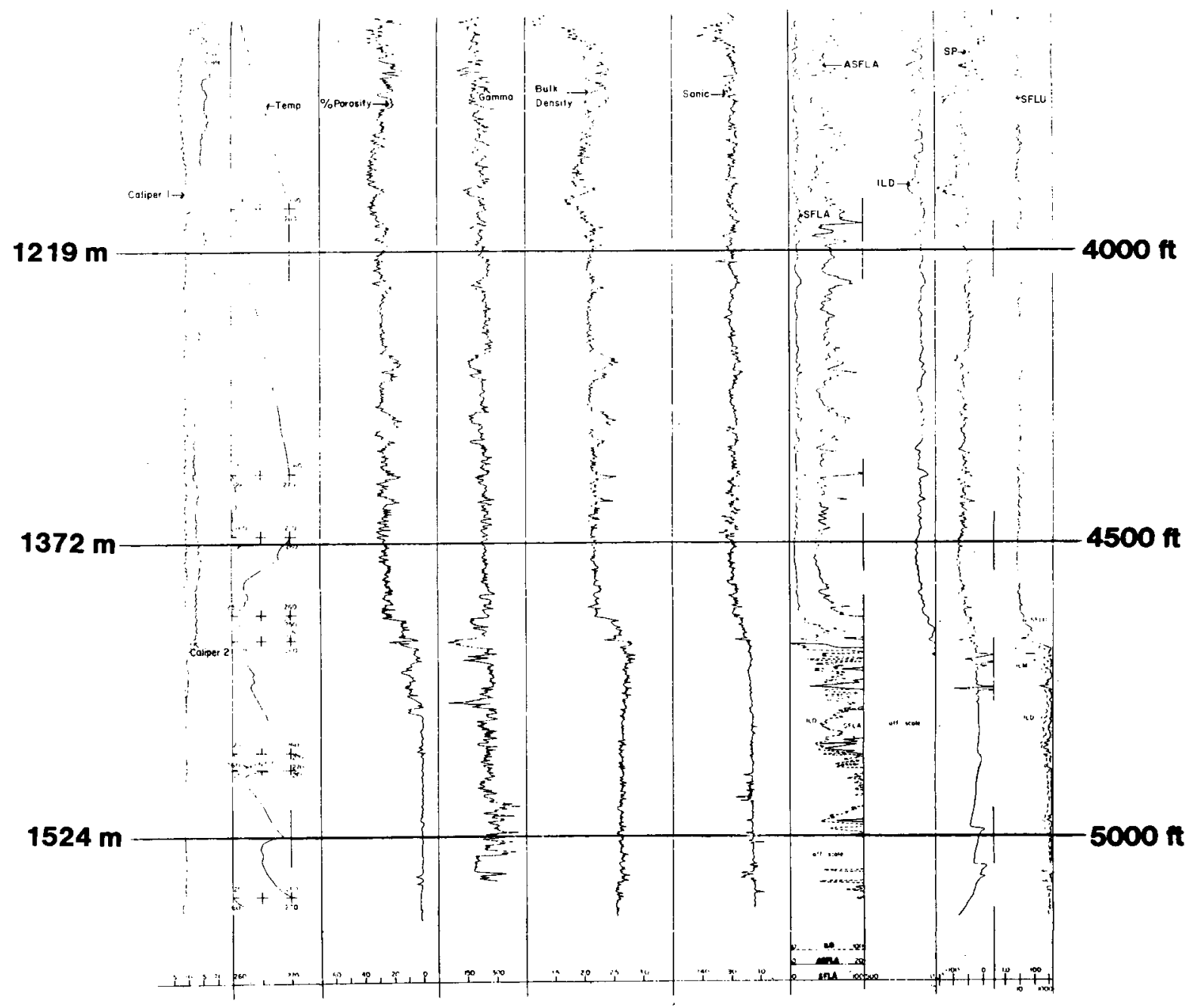

Fig. 4. Representative section of geophysical logs from RRGE No. 4. 


\section{DATA ANALYSIS}

The interpretation of geophysical logs has been refined extensively for petroleum applications. Unfortunately, the Raft River lithology is not composed of sequences; these rocks are much more complex and have log responses that are almost totally unknown. For example, in a portion of the Raft River wells, quartzite, tuff, quartz monzonite, schist, tuffaceous sandstones, and shales and silts are encountered. The log response from these materials is unique compared with the classical responses. Consequently, characteristic responses must be noted and an attempt made to understand the geological parameters causing these responses.

The first objective in the data analysis was to identify specific rock types to provide better correlation among rock types and $10 g$ responses for subsequent drilling. A second objective was to evaluate production controls, and/or to assess the ability of a given well to produce, and to define the production zone(s).

The first step was to describe a conceptual model of the resources to aid in the analysis of the data. Applegate and Donaldson (1977) have characterized the Raft River geothermal system as similar to a number of other geothermal systems in the Basin and Range and Snake River Plain areas. The model, shown in Fig. 5, relies on moving heat from within a crystalline rock toward the surface of the Earth, where the heat is trapped and concentrated beneath a debris-filled basin. The thermal conductivity is significantly lower in the basin material than in the crystalline rock. Consequently, there is a heat

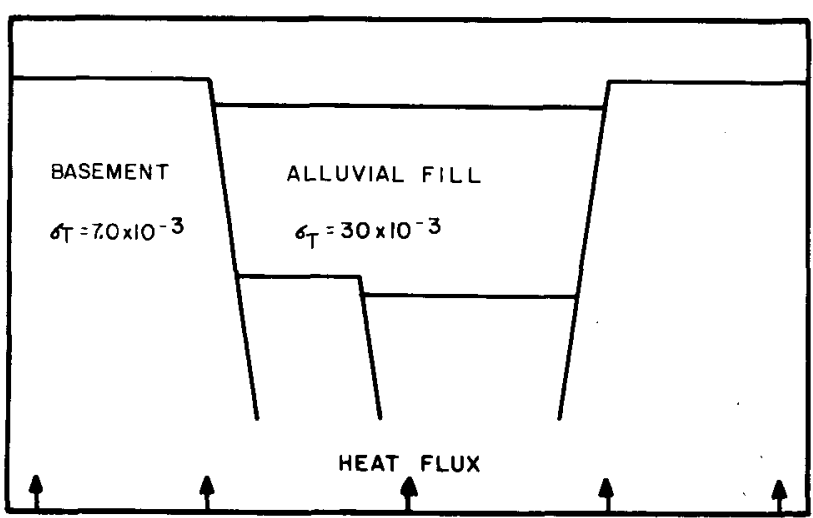

Fig. 5. Simplistic model for the Raft River geothermal system (Applegate and Donaldson, 1977). build-up at the base of the basin-fill rocks. If there are fluids and conduits (faults or fractures) that allow these fluids to circulate, then one has circulating hot fluids in the system. This is the proposed nature of the Raft River geothermal system. It has a source of water that has been heated at the base of the sedimentary rocks and has moved up through fractures into pore space created by the fracturing or into pore space in the sedimentary material. 
Although it is not germane to this discussion, it is clear that the structural controls on the Raft River geothermal system are much more complex than the diagram. In-fact, it has been suggested by Mabey et al. (1978) that thrust faulting may greatly complicate the structure. This is supported by the complexities of the lithologies in the deeper wells that suggest there may be portions of repeated Paleozoic section directly overlying the basement rock. These structural complications do not directly affect most of the log interpretation problems, but are significant in understanding the nature and origin of the porosity.

Among the several factors that must be assessed to evaluate the geothermal reservoir are the relative importance of fractures, intergranular porosity, and the effects of alteration products. It was anticipated that fractures could be a major control on the production of geothermal fluids because an extensive network of fractures would increase porosity and provide a geothermal reservoir with excellent production capabilities. The presence of apparently permeable and porous sedimentary rocks, however, suggests that these rocks may contribute to the productivity. Alteration products could be beneficial or detrimental. The alteration could produce additional porosity or the resulting alteration products could clog the porosity.

A method of defining rock types is important in assessing the nature of the porosity and the controls on the reservoir. Rock-typing information from cross-plotting techniques, porosity variations within the defined rock types, and some information from flow meters and temperature logs should aid in the determination of the production zones and their nature. Each formation can be thought of as having four components that will determine the response to the various porosity tools ( $F i g .6$ ): the formation matrix, which in itself can be quite complex; alteration products; pore (intergranular) porosity; and fracture porosity. Each porosity tool should respond a little differently to these four components. For example, the neutron log may detect the alteration products with their water of hydration as porosity; and may detect the fracture porosity, whereas the sonic log may detect some effect from the alteration products, but may not detect the effects of fractures. Therefore, we thought that the difference in response might be diagnostic. With these thoughts in mind, and after examination of the geophysical logs, it was decided that the three porosity tools (sonic, density, and neutron) provided the most usable 
DENSITY

$$
\begin{aligned}
& \rho_{B}=\rho_{M} F_{M}+\rho_{A P} F_{A P}+\rho_{W W_{F}}+\rho_{W} \phi_{P} \\
& F_{M}+F_{A P}+\phi_{F}+\phi_{P}=1
\end{aligned}
$$

SONIC

$$
\begin{aligned}
& \Delta T=\frac{1}{V}=\frac{\phi_{P}}{V_{W}}+\frac{K_{1} \phi_{F}}{V_{W}}+\frac{F_{M}}{V_{M}}+\frac{F_{A P}}{V_{A P}} \\
& \phi_{P}+K_{1} \phi_{F}+F_{M}+F_{A P}=1
\end{aligned}
$$

NEUTRON

$$
\phi_{n}={ }_{P}^{\phi}+{ }_{F}+K_{2} F_{A P}
$$

DEFINITIONS:

$$
\begin{aligned}
\rho_{B}= & \text { bulk density } \\
\rho_{M}= & \text { matrix density } \\
F_{M}= & \text { fractional proportion of } \\
& \text { matrix } \\
\rho_{A P}= & \text { alteration product density } \\
F_{A P}= & \text { fractional proportion of } \\
& \text { alteration products } \\
D_{W}= & \text { water density } \\
\Phi_{F}= & \text { fracture porosity } \\
\Phi_{P}= & \text { pore porosity }
\end{aligned}
$$

$$
\begin{aligned}
\Delta T & =\text { transit time } \\
V & =\text { velocity of formation } \\
V_{W} & =\text { fluid velocity } \\
V_{M} & =\text { matrix velocity } \\
V_{A P} & =\text { alteration product velocity } \\
K_{1}, & K_{2}=\text { constants } \\
\phi_{n} & =\text { neutron porosity }
\end{aligned}
$$

Fig. 6. Log response equations of a simplistic model of the rocks in the Raft River geothermal system.

data for interpretation, and we concentrated on analysis schemes using data from these tools.

Several approaches were considered to solve the problems. The principal approach involved several standard cross-plotting techniques, such as sonic-density, neutron-density, and sonic-neutron. These cross plots, shown in Figs. 7 to 15, clearly delineate the major rock types within the PaleozoicPrecambrian section and in a portion of the younger rocks overlying the Paleozoics.

Figures 7 and 8 show data from RRGE No. 1 for the depth interval from $1392 \mathrm{~m}(4568 \mathrm{ft})$ to $1525 \mathrm{~m}(5002 \mathrm{ft})$. On both plots, the quartzite data points 
are well grouped, whereas the schist data are more scattered. On both graphs, however, the data do not follow the $45^{\circ}$ line of one-to-one correspondence that is characteristically seen for sedimentary rocks. This departure suggests that the metamorphics have other factors affecting their response such as porosity type and distribution and mineralogy.

Figures 9 through 12 show cross-plot data from RRGE No. 2. Figure 9 shows data from $1158 \mathrm{~m}(3800 \mathrm{ft})$ to $1275 \mathrm{~m}(4184 \mathrm{ft})$. The rocks in this section are from the Tertiary Salt Lake Formation. The sandstone and siltstone

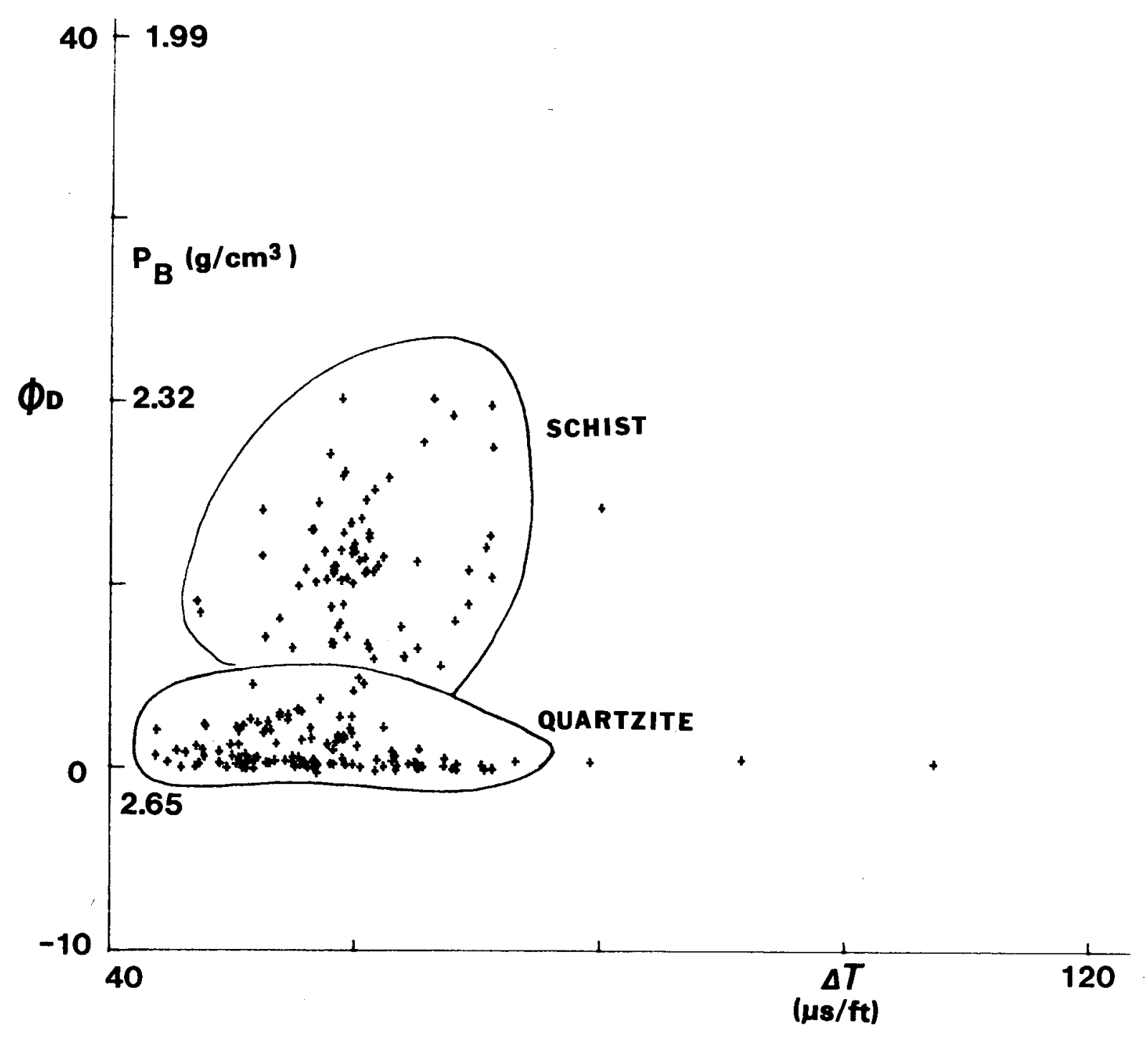

Fig. 7. Plot of $\$$ sandstone (ss) vs $\Delta T$ for the depth interval $1392 \mathrm{~m}$ $(4568 \mathrm{ft})$ to $1525 \mathrm{~m}(5002 \mathrm{ft})$ in RRGE No. 1. 


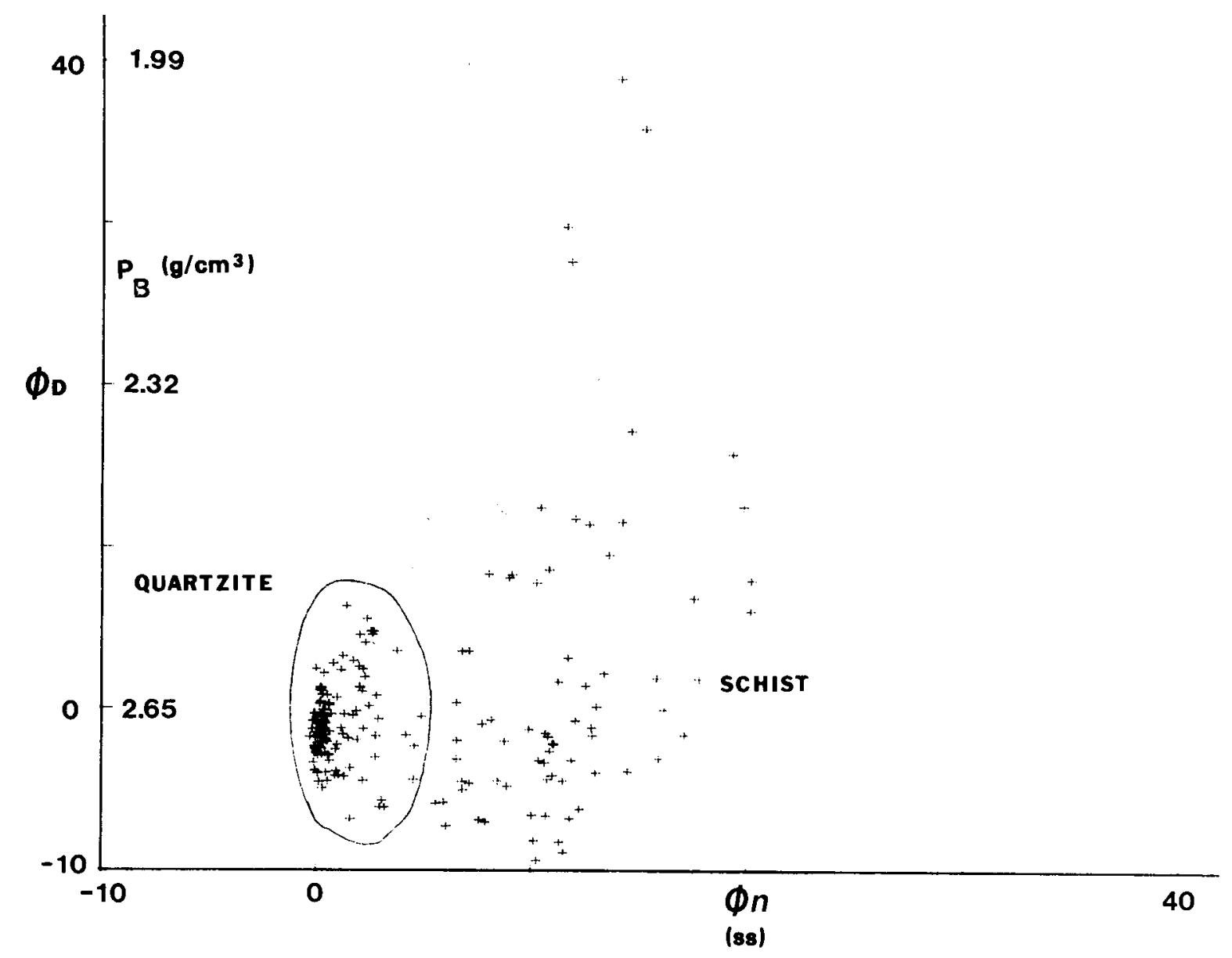

Fig. 8. Plot of $\phi_{\mathrm{D}}$ (ss) vs $\phi_{\mathrm{n}}$ (ss) for the depth interval $1392 \mathrm{~m}$ (4568 ft) to $1525 \mathrm{~m}$ (5002 ft) in RRGE No. 1.

can be broken into distinct rock types by cross plotting $\phi_{D}$ (density-derived porosity) vs $\Delta T$ (sonic transit time). Figures 10 through 12 are data from

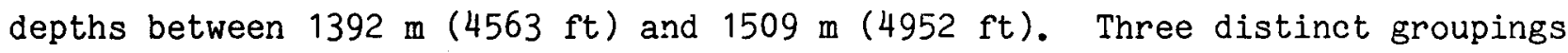
are seen on these plots for the three rock types--sandstone (Salt Lake Formation), schist, and quartzite. On all these cross plots, $\phi_{D} v s \Delta T, \phi_{D}$ vs $\phi_{n}$ (neutron-derived porosity) and $\phi_{n}$ vs $\Delta T$, the sandstone follows the characteristic pattern of sedimentary rocks. The metamorphics do not fit this pattern. 


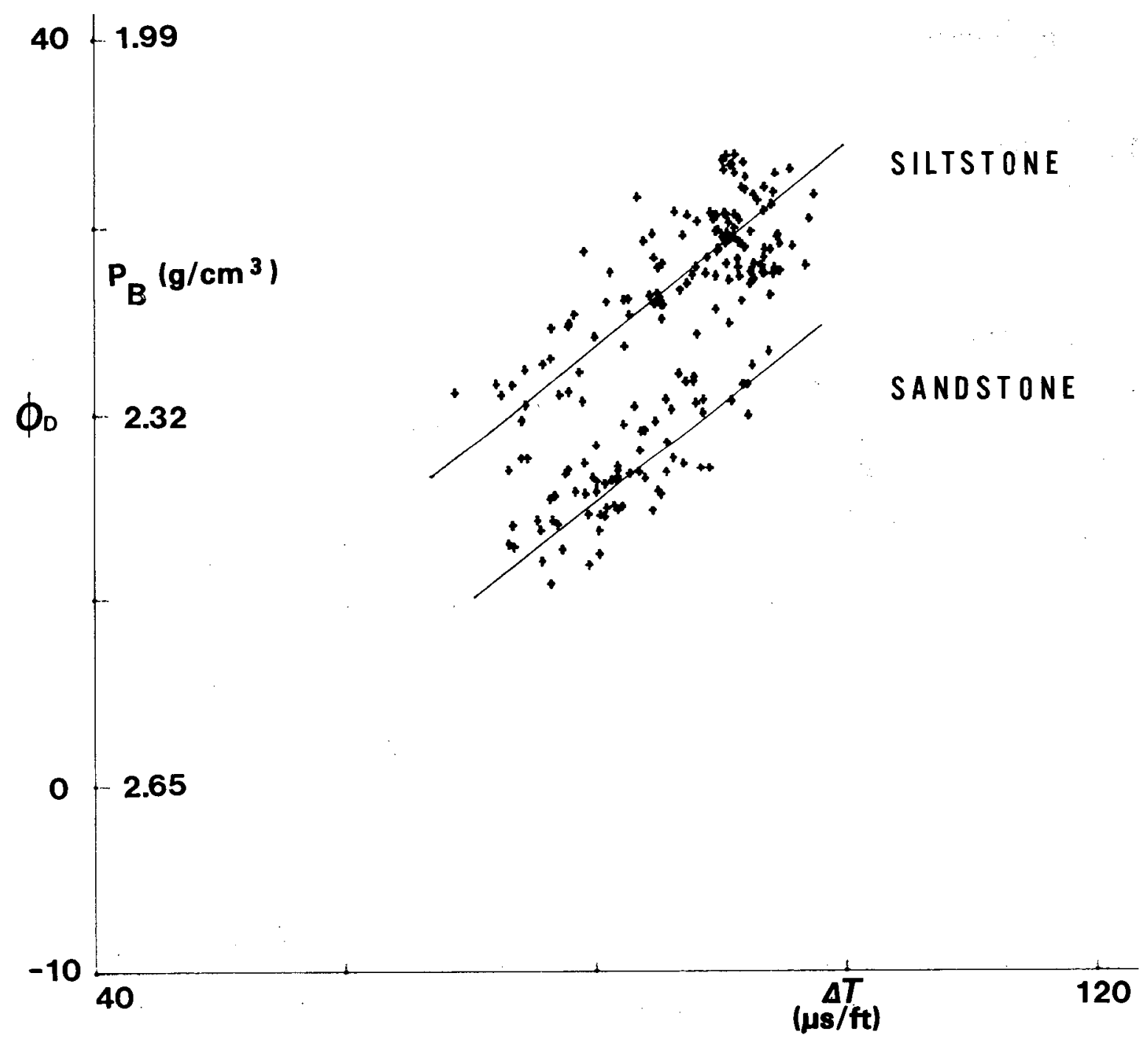

Fig. 9. Plot of $\phi_{D}$ (ss) vs $\Delta T$ for the depth interval $1158 \mathrm{~m}$ (3800 ft) to $1275 \mathrm{~m}$ (4184 ft) in RRGE No. 2. 


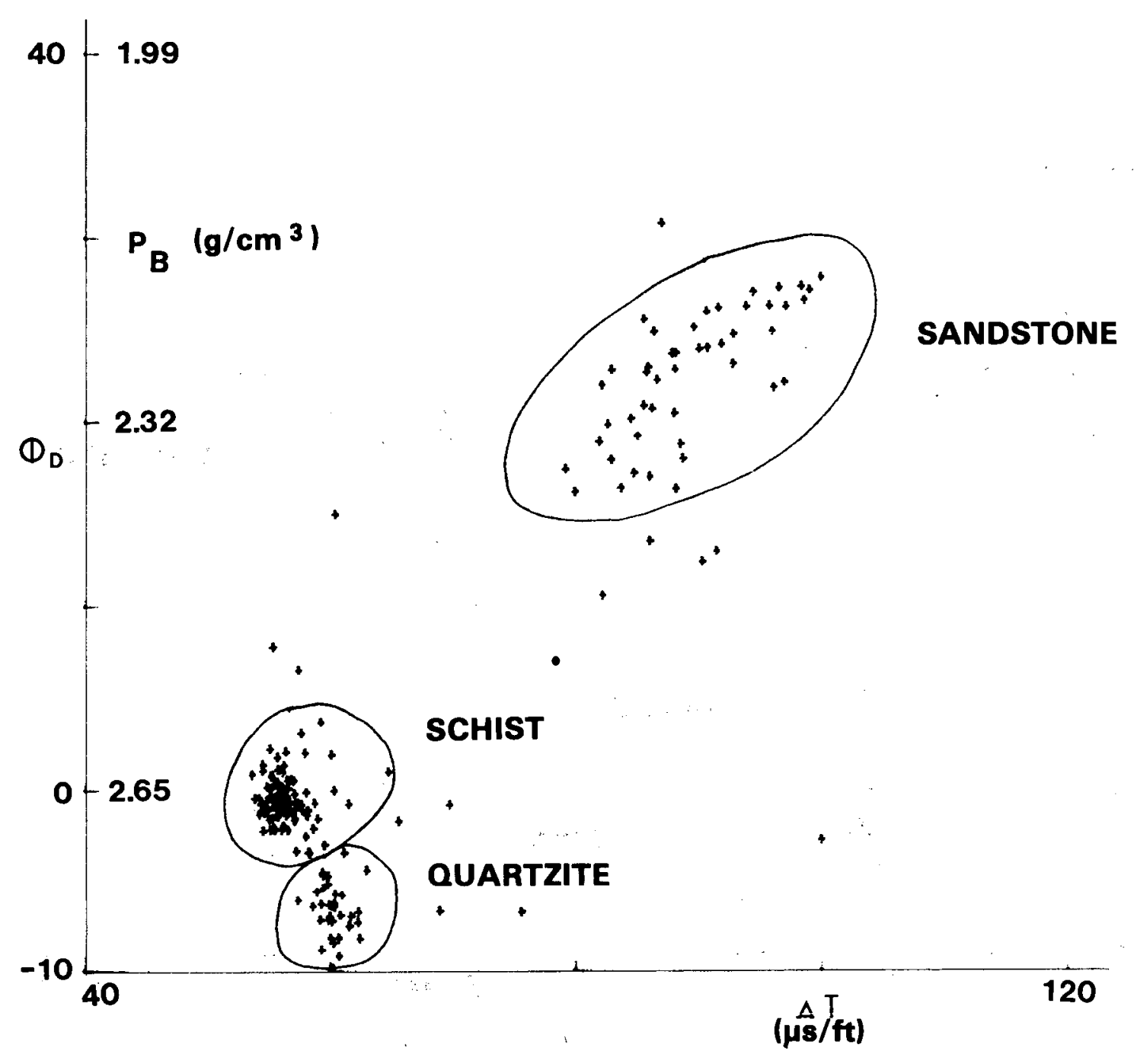

Fig. 10. Plot of $\phi_{D}$ (ss) vs $\Delta T$, for the depth interval $1392 \mathrm{~m}$ (4568 ft) to $1509 \mathrm{~m}$ ( $4952 \mathrm{ft}$ ) in RRGE No. 2. 


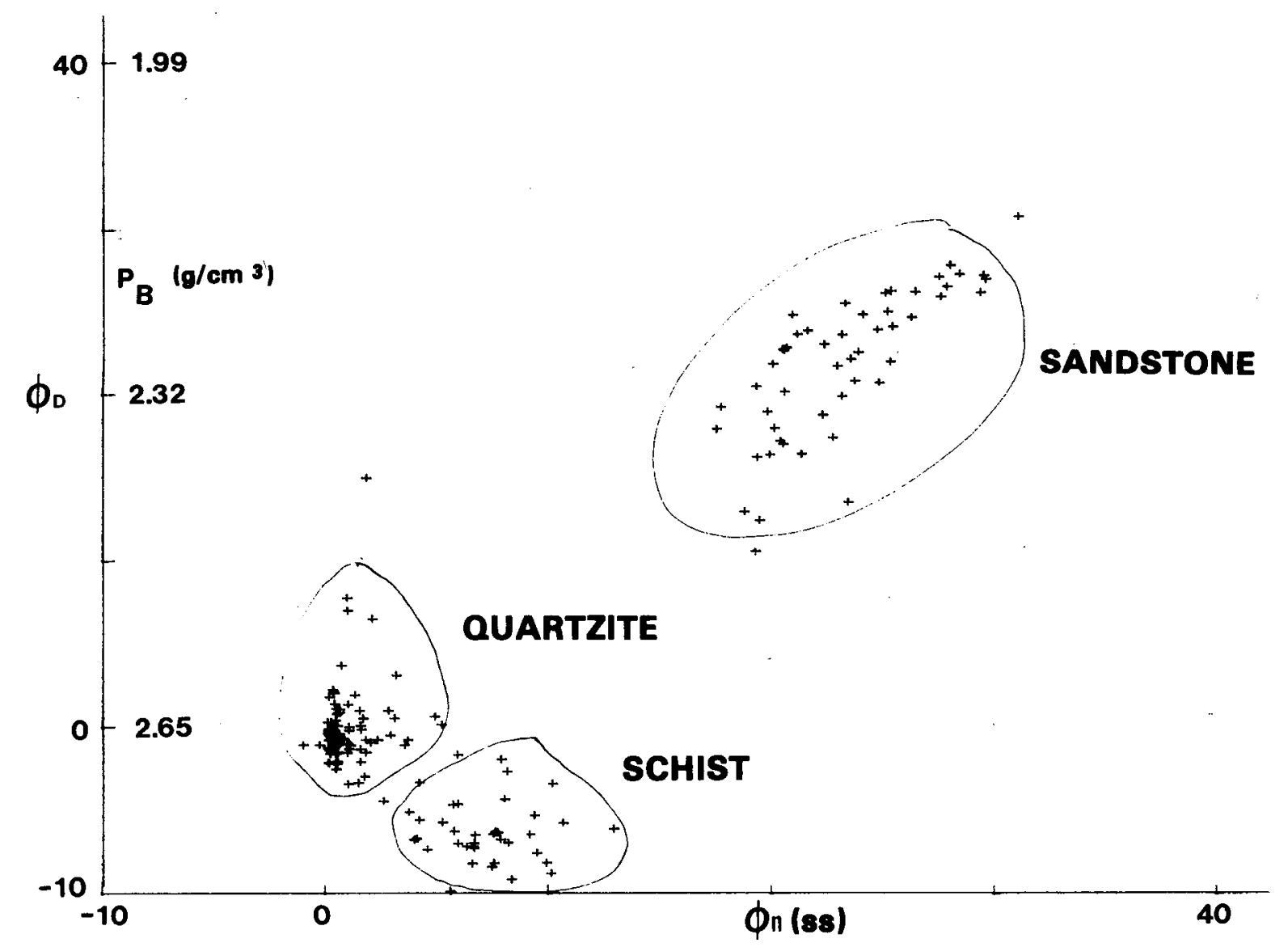

Fig. 11. Plot of $\phi_{D}$ (ss) vs $\phi_{n}$ (ss) for the depth interval 1392 w (4568 ft) to $1509 \mathrm{~m}$ (4952 ft) in RRGE No. 2. 


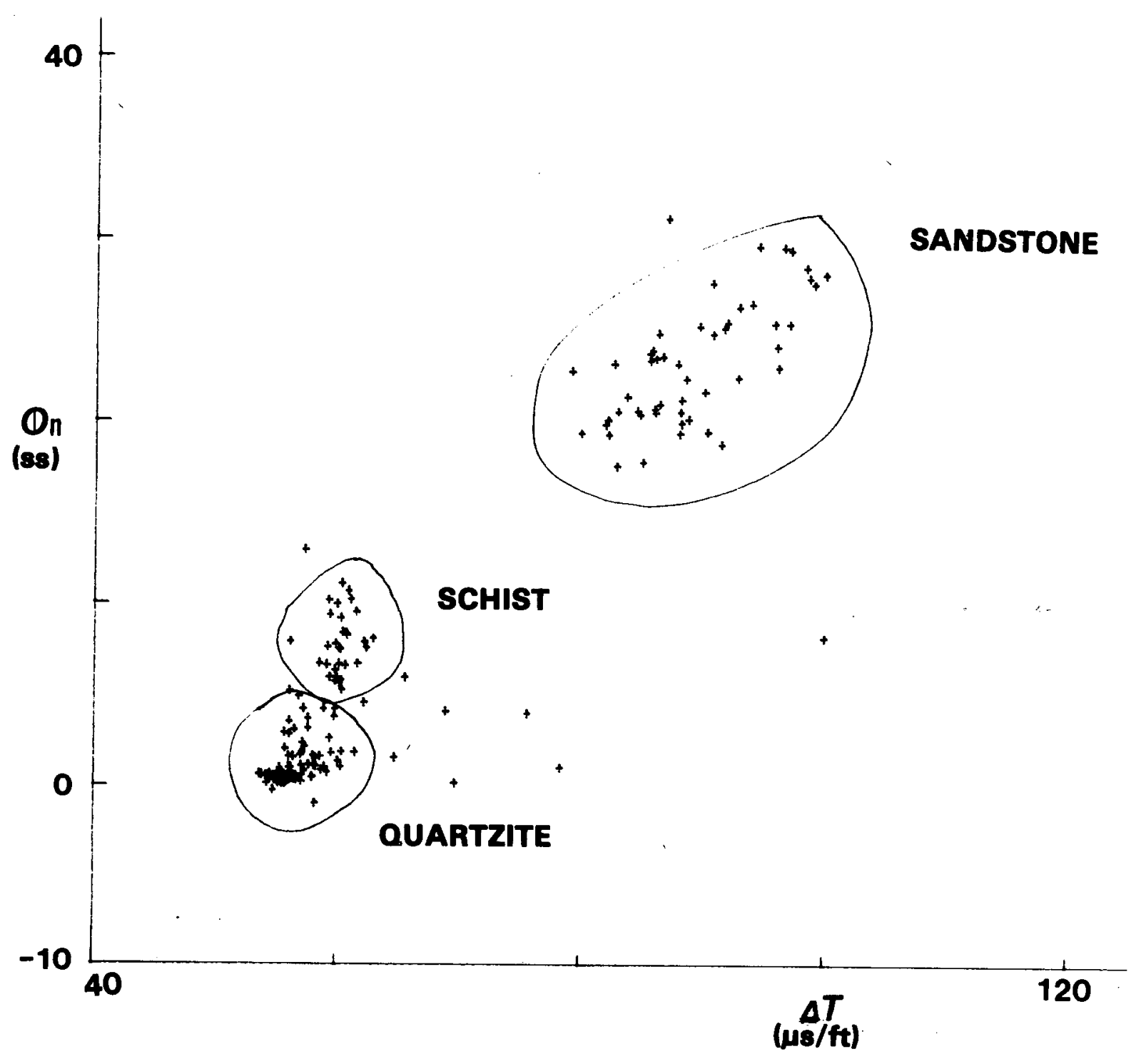

Fig. 12. Plot of $\phi_{n}$ (ss) vs $\Delta T$ for the depth interval $1392 \mathrm{~m}$ (4568 ft) to $1509 \mathrm{~m}$ (4952 ft) in RRGE No. 2. 
Figures 13 through 15 are cross plots of the same parameters for the depth interval $1408 \mathrm{~m}(4618 \mathrm{ft})$ to $1539 \mathrm{~m} \mathrm{(5050} \mathrm{ft)} \mathrm{in} \mathrm{RRGE} \mathrm{No.} \mathrm{4.} \mathrm{Again,}$ three distinct groups became apparent--siltstone, schist, and quartzite. The siltstone fits the sedimentary pattern, whereas the metamorphics fall into relatively tight groups. In fact, for the plot of $\phi_{D}$ vs $\phi_{n}$, the elongate trend is orthogonal to the standard trend. A review of the data for other wells shows a similar pattern. This pattern is, undoubtedly, very strongly influenced by the mineralogy as well as porosity.

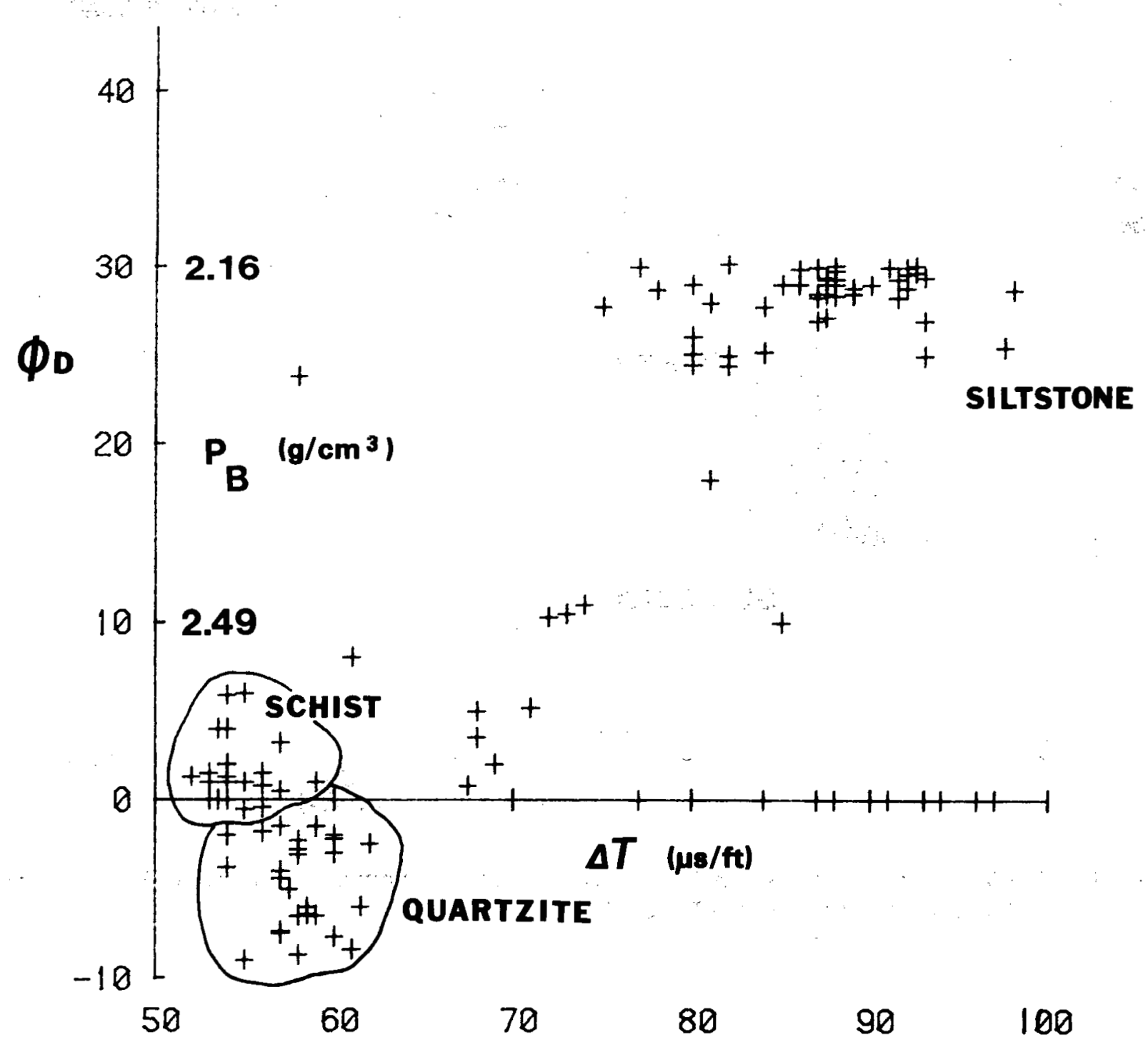

Fig. 13. Plot of $\phi_{D}$ (ss) vs $\Delta T$ for the depth interval $1408 \mathrm{~m}$ (4618 ft) to $1539 \mathrm{~m}$ (5050 ft) in RRGE No. 4. 
The problems of mineralogy appear to be significant when the effects of alteration are considered. Both the schist and the quartzite have a fairly complex mineralogy. The schist is described by Corrington (1977) as dark brown to gray, fine- to medium-grained biotite schist, and fine-grained gneiss that contains quartz or quartz-feldspar lenses, and the quartzite is described as white, tan, or locally pale green quartzite with muscovite-quartz schist between some beds. This makeup suggests that alteration should be considered.

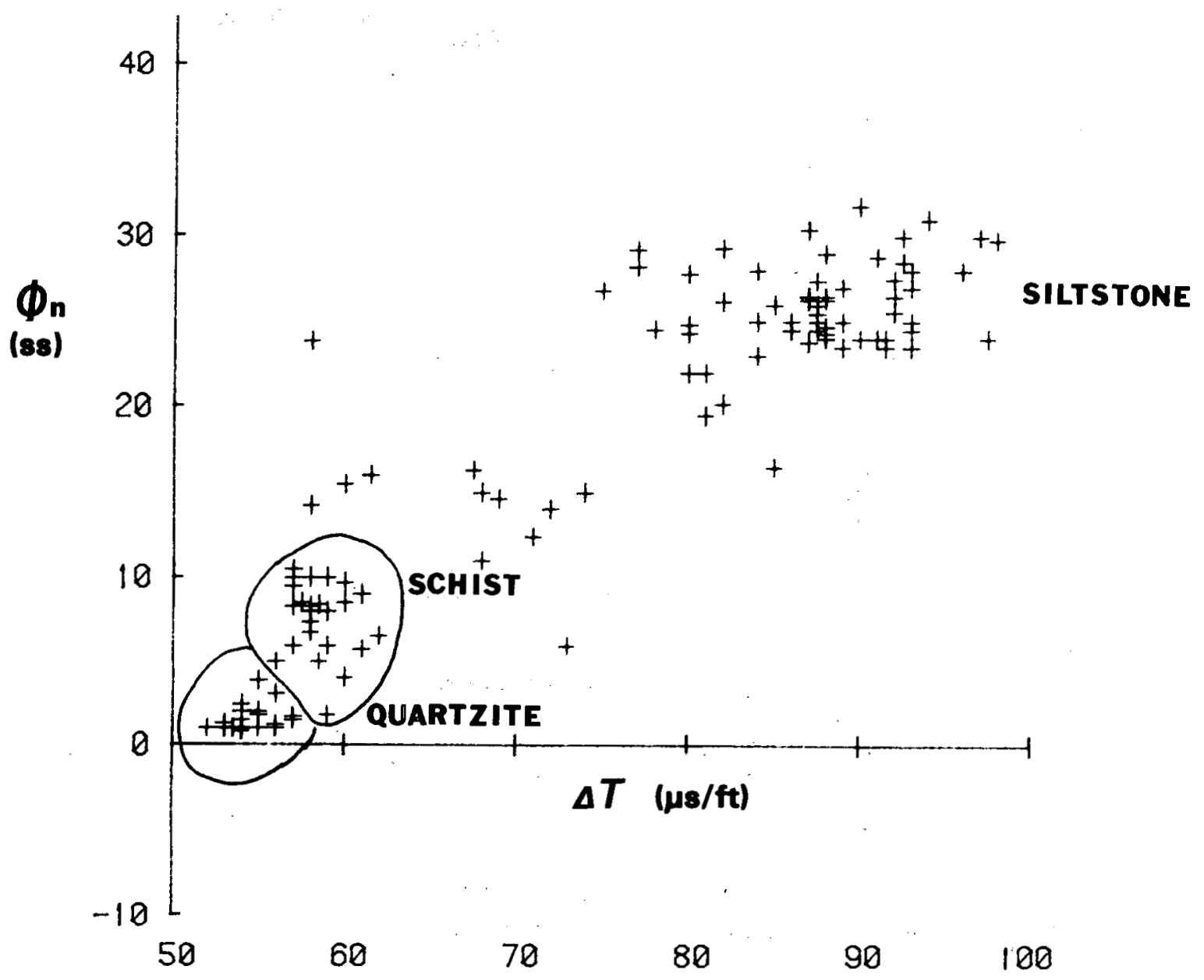

Fig. 14. Plot of $\phi_{\mathrm{h}}$ (ss) vs $\Delta \mathrm{T}$ for the depth interval $1408 \mathrm{~m}$ (4618 ft) to $1539 \mathrm{~m}$ (5050 ft) in RRGE No. 4. 


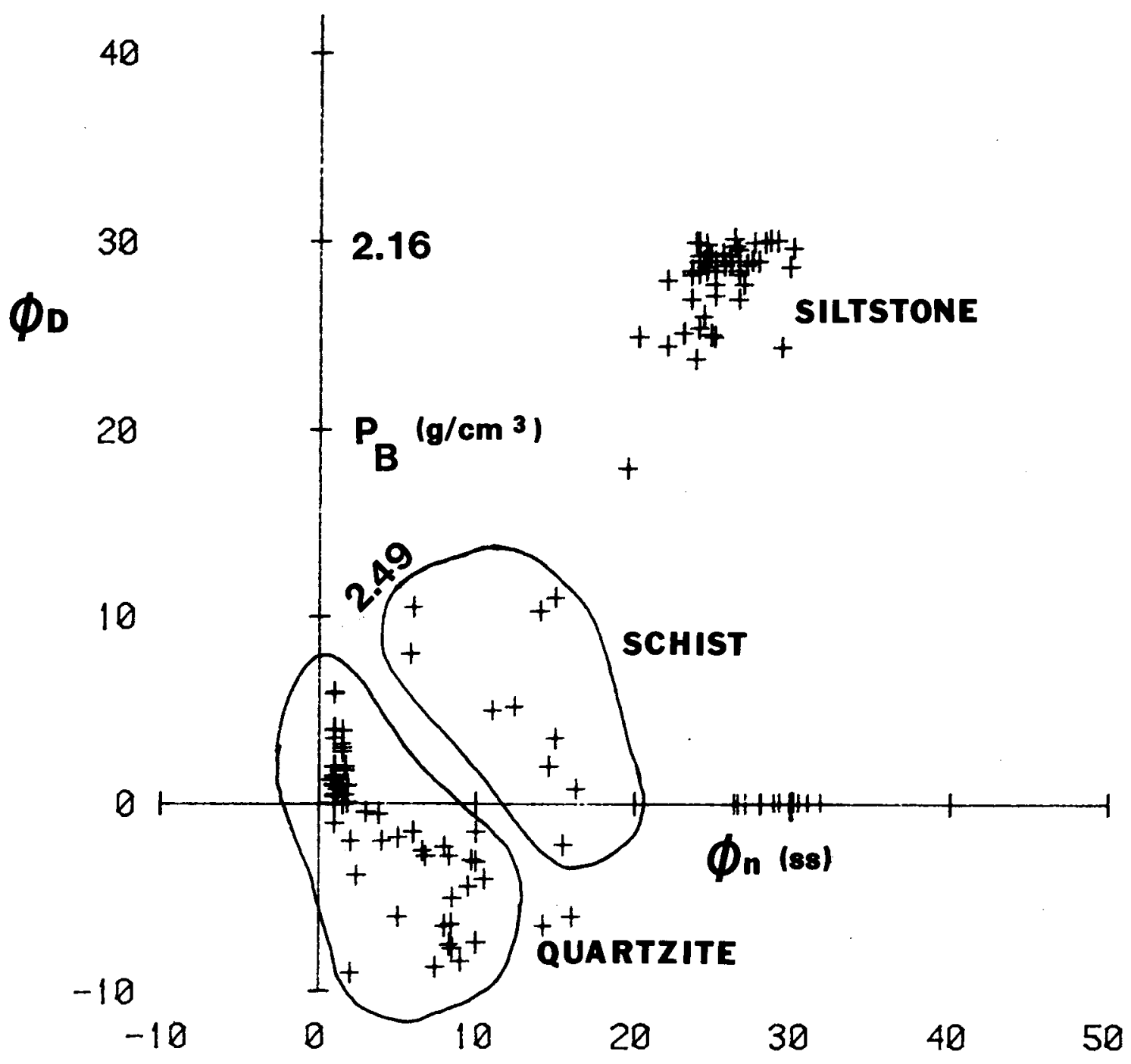

Fig. 15. Plot of $\phi_{\mathrm{D}}$ (ss) vs $\phi_{\mathrm{n}}$ (ss) for the depth interval $1408 \mathrm{~m}$ (4618 ft) to $1539 \mathrm{~m}(5050 \mathrm{ft}$ ) in RRGE No. 4. 
A change in the properties could result from alteration of mafic minerals in the schist and/or quartzite to clay minerals. This decrease in the percentage of mafic minerals and increase in the amount of clay minerals would result in a decrease in density, and perhaps a reduction in pore space, which could account for some of the strange trends seen on the $\phi_{D}$ vs $\phi_{n}$ cross plot. The same effect has been noted by Glenn and Hulen (1979), who determined the makeup of rock in Sec. 14-2 of Utah State Geothermal that had been logged. Glenn and Hulen's data are shown in Fig. 16. For the main constituents of the rocks, a grain density of $2.71 \mathrm{~g} / \mathrm{m}^{3}$ was used, and a density of $3.15 \mathrm{~g} / \mathrm{m}^{3}$ was used for the mafics. The volume of bound water in the mafics is 10\%. The grid illustrated in Fig. 16 would change as the densities vary (contract or expand) and rotate as the bound water percentage changed. The grid rotates counter clockwise as the bound water percentage increases.

With this model, several observations can be noted on Figs. 8, 11, and 15. First, the data points represent more altered rock for increased $\phi_{D}$ (decreased bulk intensity) for a given rock type. Second, the mafic mineral composition and/or the percentage of bound water may vary somewhat from well to well. Third, the quartzite-schist relationship is consistent for RRGEs No. 1 and No. 2, whereas it is different for RRGE No. 4.

From these data, we surmised that both the quartzite and schist, at least in part, are more altered in RRGE No. 4 than in RRGE No. 1 and No. 2. This is indicated by the "up-to-the-left" shift of most of the schist data points, and the elongation of the trend of the quartzite points in the same direction. The indicated increase in alteration may have clogged the porosity (pores or fractures) to the point that permeability is reduced and production minimized.

From these data, we can speculate on the degree of alteration; however, it does not appear possible to draw definitive conclusions about the nature of the porosity in the production zones. Therefore, we evaluated other parameters to obtain information on porosity type and distribution. One parameter was based on the difference between the transit time in microseconds and the density-derived porosity in percent divided by the transit time. This parameter is shown on cross plots as

$$
Q=\frac{\Delta T-\phi_{D}}{\Delta T} \text {. }
$$




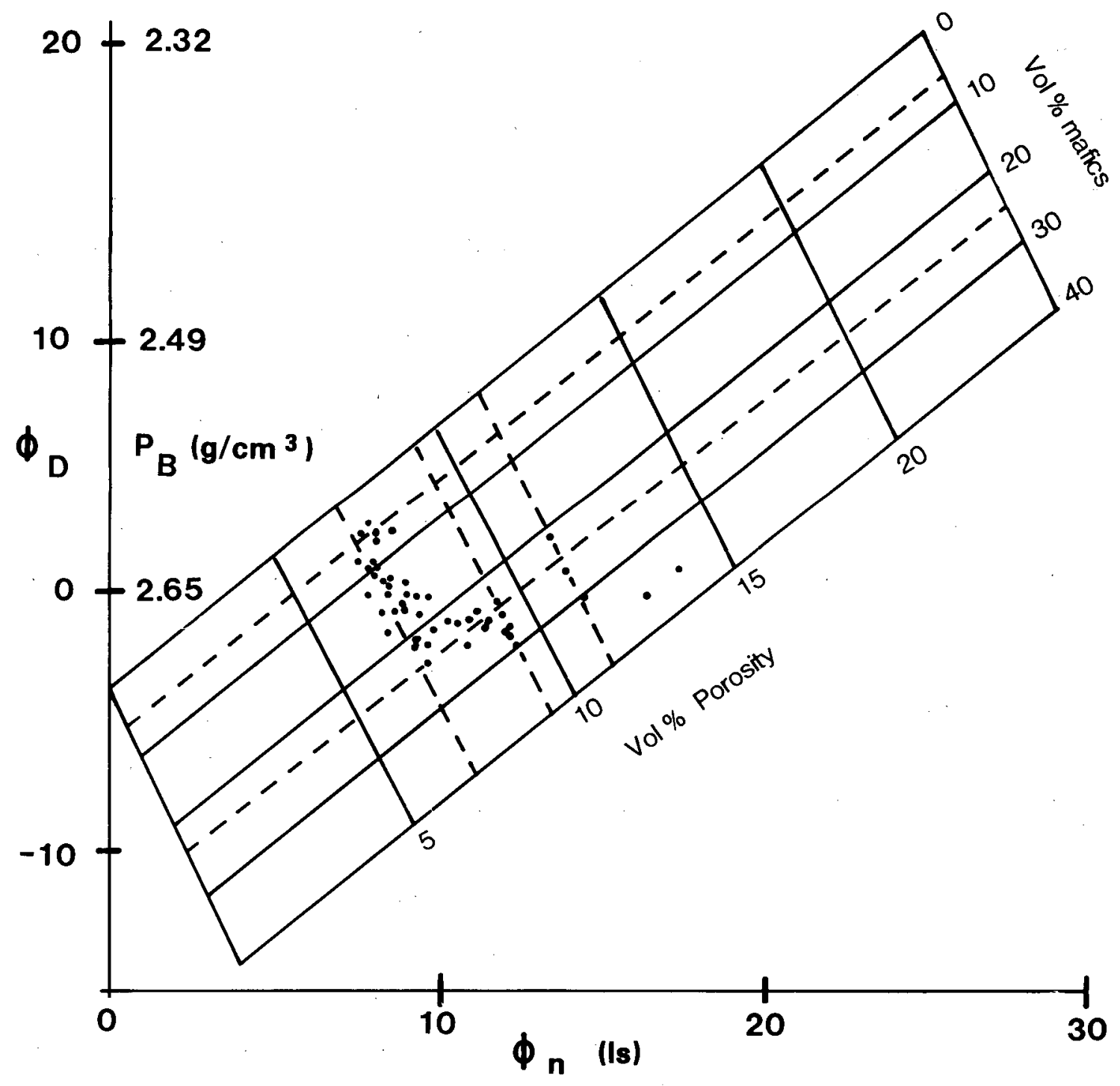

Fig. 16. Plot of $\phi_{D}$ (ss) vs $\phi_{n}$ (1s) for Utah State Geothermal Well 14-2. Depth interval $457 \mathrm{~m}(1500 \mathrm{ft})$ to $488 \mathrm{~m}(1600 \mathrm{ft})$, is $=$ $2.71 \mathrm{~g} / \mathrm{m}^{3}, \rho \mathrm{m}=3.15 \mathrm{~g} / \mathrm{m}^{3}$, and vol\% $\mathrm{H}_{2} \mathrm{O}$ in mafics is $10 \%$. 
and is affected by changes in the bulk density and the velocity or transit time. These factors (density and velocity) also define elastic moduli. Therefore, $Q$ may be thought of as both the difference between two different porosity responses and as a strength parameter. Changes in the velocity-density relationship should result in changes in slope, and the different rock types should be distributed in somewhat different porosity ranges. Alteration products and/or fracturing should cause a change in slope (a flattening) and scatter within a given rock type.

Figures 17 through 21 show $Q$ cross plotted vs $\phi_{D^{*}}$ Figure 17 shows

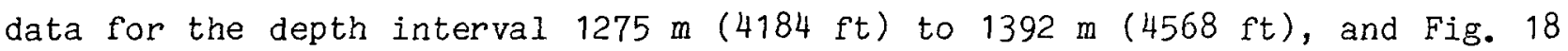
shows data for the interval $1392 \mathrm{~m}$ (4568 ft) to $1525 \mathrm{~m}$ (5002 ft), both from RRGE No. 1. Several distinct patterns are seen for the various rock types. The quartz monzonite plot shows some scatter that indicates a variation in the velocity-density relationship with the formation, which is probably indicative of fracture distribution. The quartzite has a very tight data grouping that probably indicates either very little porosity or a very consistent porosity distribution within the unit. This implies that the quartzite has very few, if any, fractures. The schist data points on both Figs. 17 and 18 are more scattered, which suggests that the velocity-density relationship varies greatly within the unit, and thus may indicate significant fracturing within the schist. The tuffaceous siltstone is complex in lithology and also complex in its response. There is a distinct trend that may indicate variation in the basic pore porosity within the unit, but the scatter probably indicates that the siltstone has significant fractures.

Figures 19 and 20 are plots of $Q$ vs $\phi_{D}$ for RRGE No. 2. Figure 19 is for the interval from $1392 \mathrm{~m}$ (4563 ft) to $1509 \mathrm{~m}$ (4952 ft) whereas Fig. 20 is

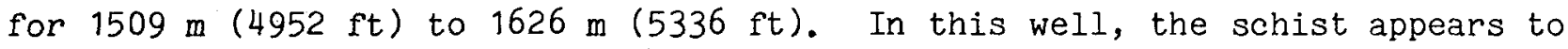
have a singular velocity-density relationship, which implies less fracturing. The sandstone shows some data point scatter, which may indicate fracturing. The quartzite and the quartz monzonite show some scatter in the data points, which may be indicative of fracturing. From these data, one would anticipate some production is coming from the sandstone, the quartzite, and the quartz monzonite. A check of individual data points should better pinpoint the individual production zones.

Figure 21 is $Q$ vs $\phi_{D}$ for RRGE No. 4 for the interval $1408 \mathrm{~m}$ (4618 ft) to $1593 \mathrm{~m}$ (5050 ft). The schist and quartzite are described by a very linear 


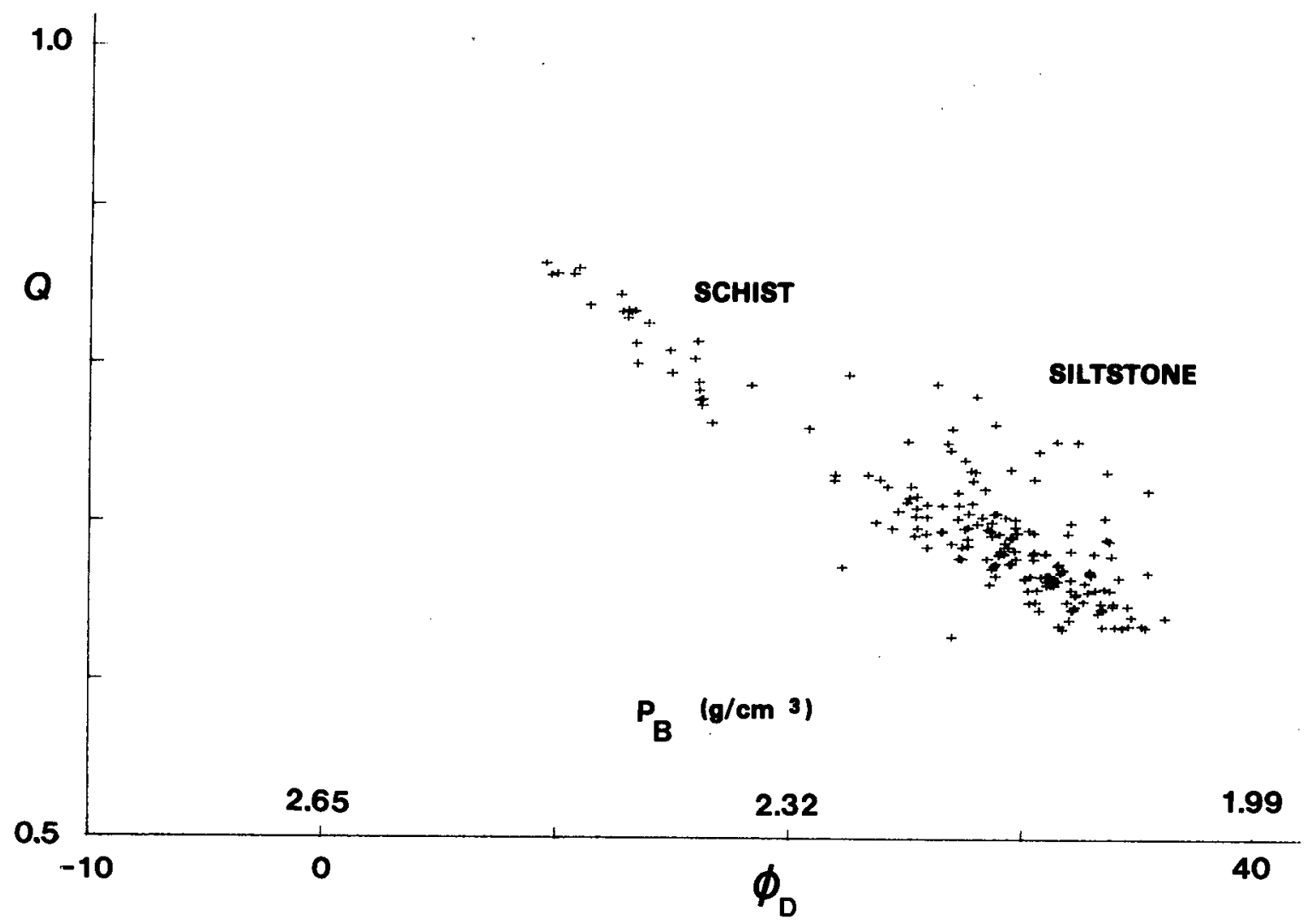

Fig. 17. Plot of $Q$ vs $\phi_{D}$ (ss) for the depth interval $1275 \mathrm{~m}$ (4184 ft) to $1392 \mathrm{~m}$ (4568 ft) in RRGE No. 1. 


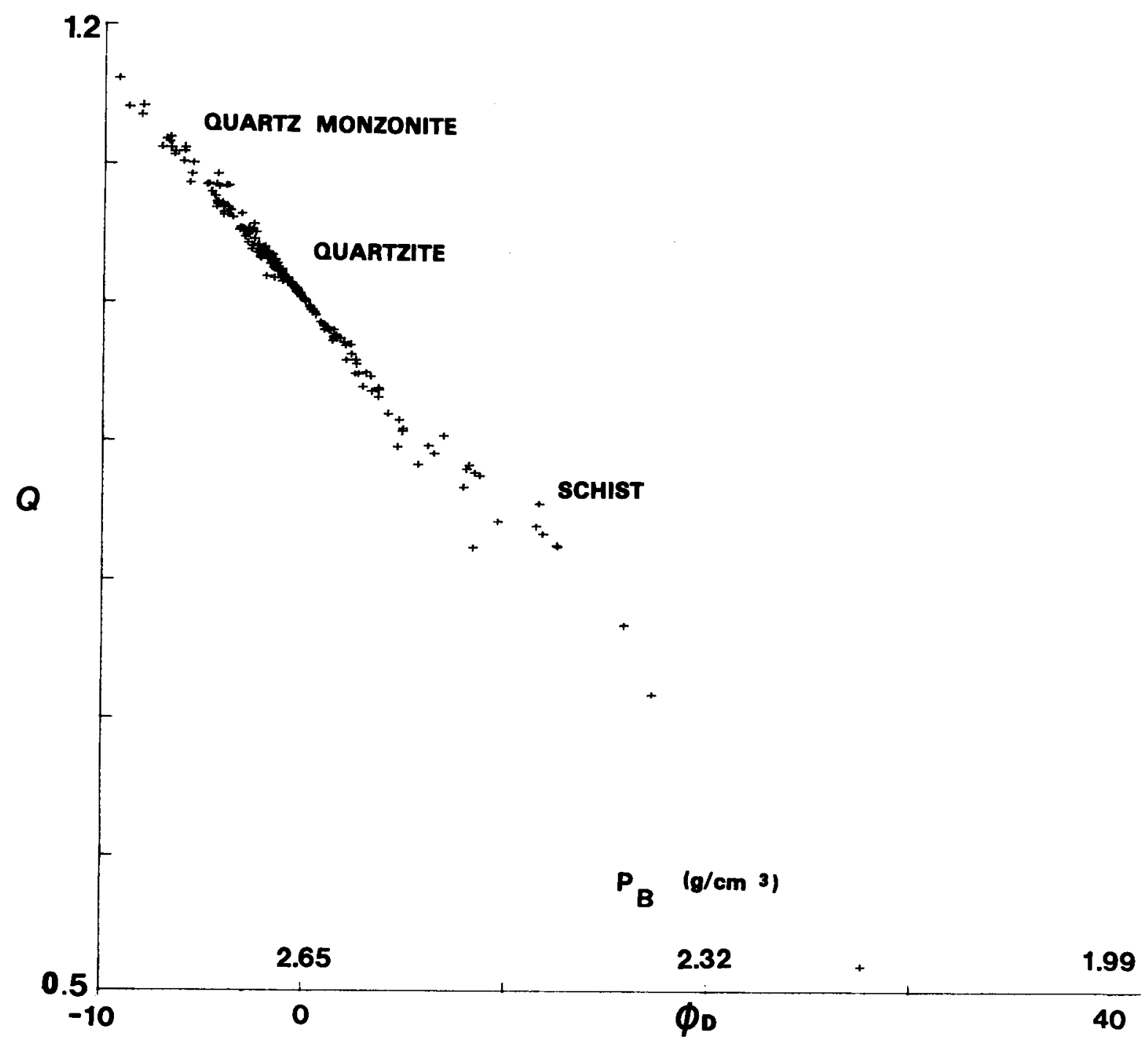

Fig. 18. Plot of $Q$ vs $\phi_{D}$ (ss) for the depth interval $1392 \mathrm{~m}$ (4568 ft) to $1525 \mathrm{~m}(5002 \mathrm{ft})$ in RRGE No. 1 


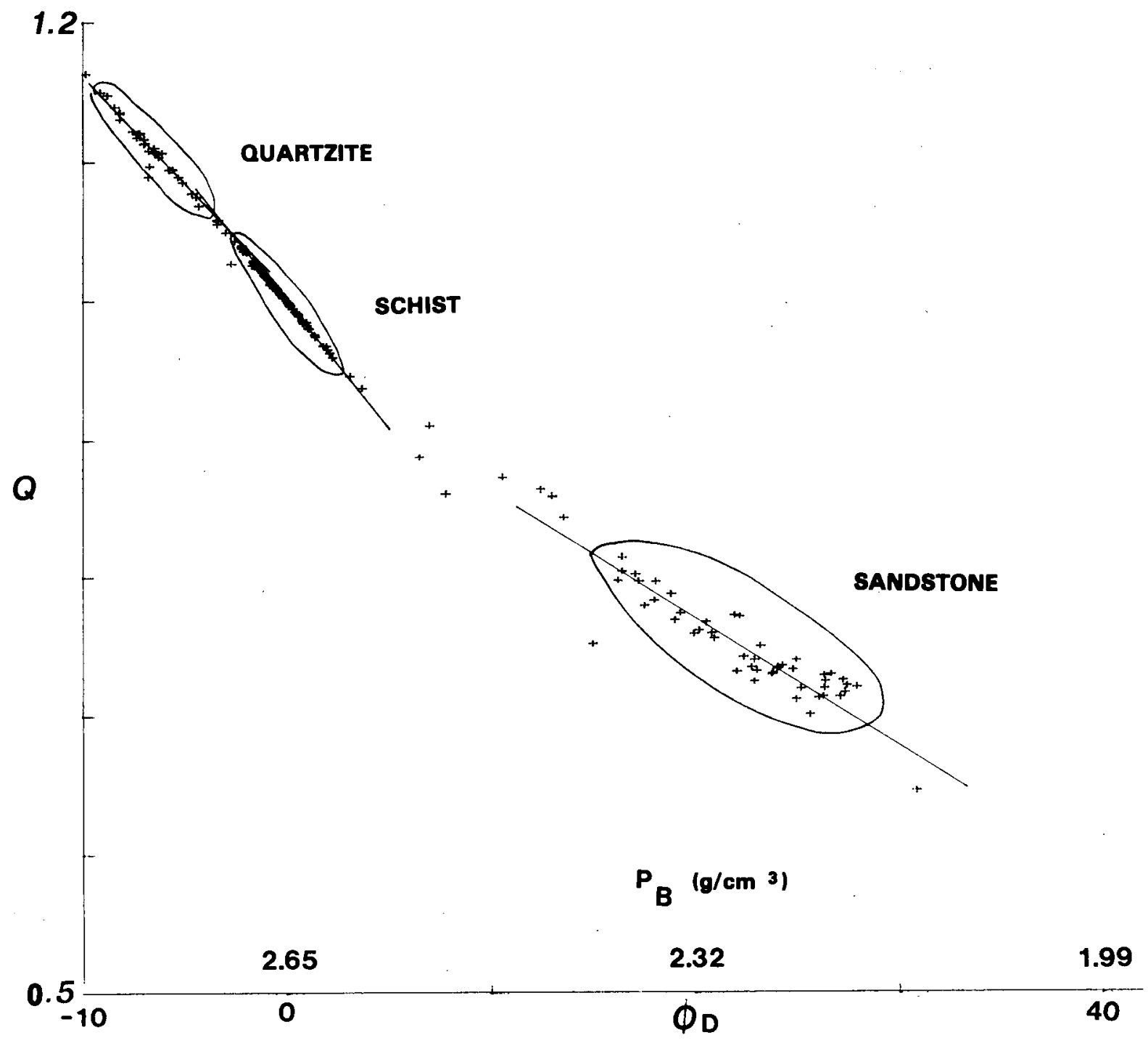

Fig. 19. Plot of $Q$ vs $\phi_{D}$ (ss) for the depth interval $1392 \mathrm{~m}$ (4568 ft) to $1509 \mathrm{~m}$ (4952 ft) in RRGE No. 2. 


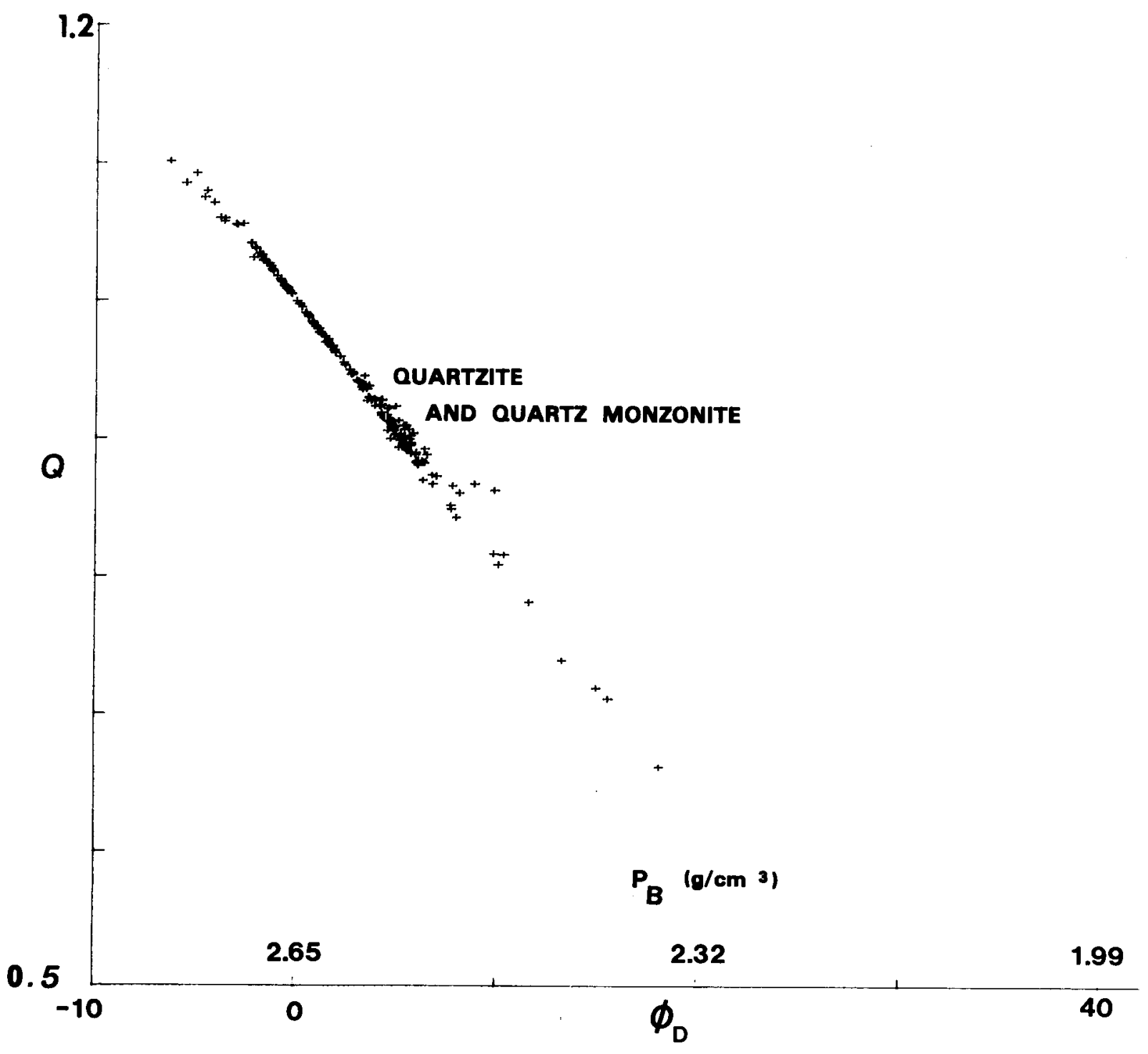

Fig. 20. Plot of $Q$ vs $\phi_{D}$ (ss) for the depth interval $1509 \mathrm{~m}$ (4952 ft) to $1626 \mathrm{~m}$ (5336 ft) in RRGE No. 2. 


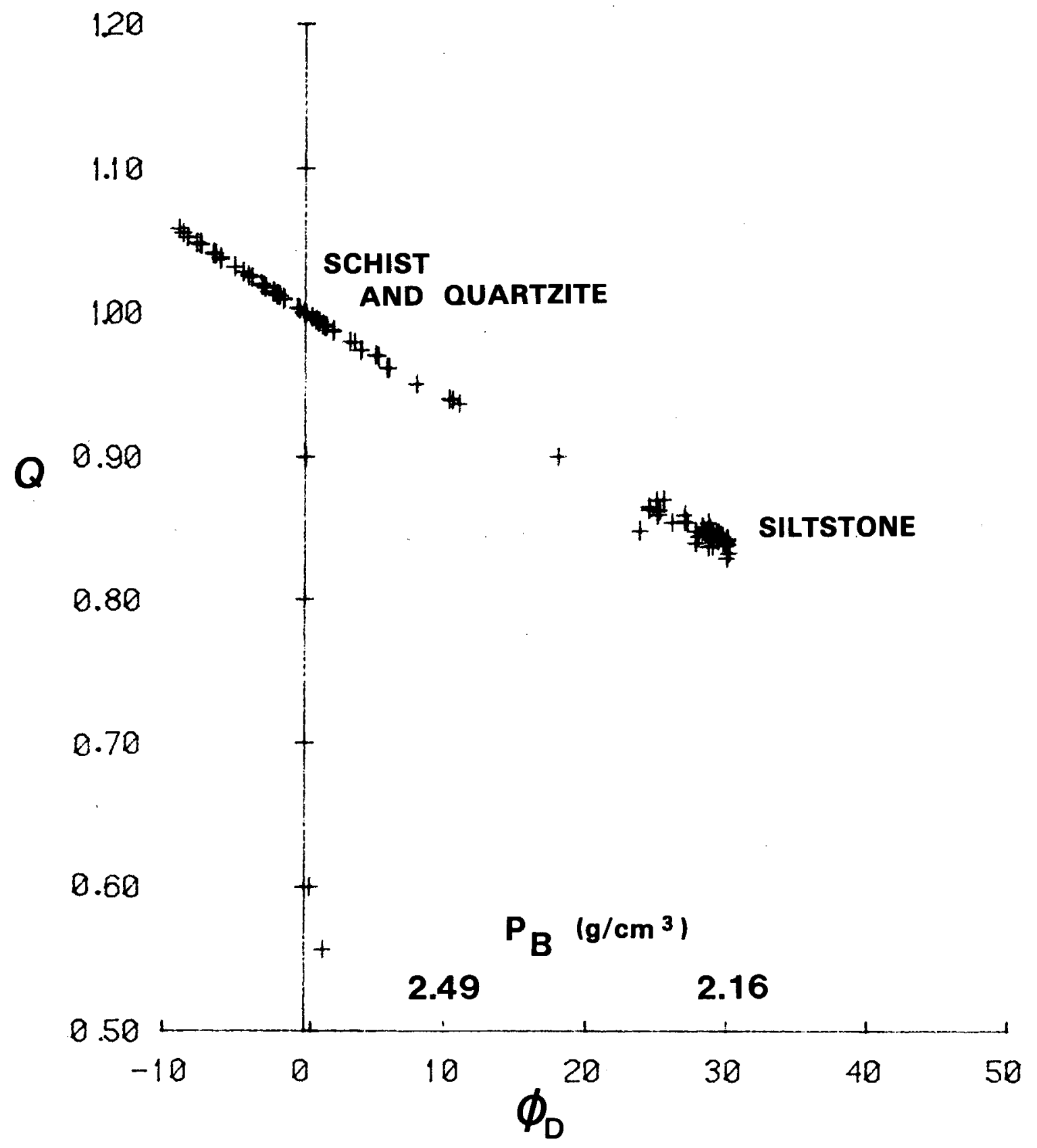

Fig. 21. Plot of $Q$ vs $\phi_{D}$ (ss) for the depth interval $1408 \mathrm{~m}$ (4618 ft) to $1539 \mathrm{~m}$ (5050 it) in RRGE No. 4. 
set of data points, which implies little if any fracturing. Even the siltstone shows a very tight grouping of data points implying little fracturing.

Of numerous other cross plots generated, some showed promise, but need more analysis. One interesting plot was

$$
\frac{\phi_{\mathrm{n}}-\phi_{\mathrm{D}}}{\phi_{\mathrm{D}}} \operatorname{vs} \phi_{\mathrm{D}} .
$$

An increase in

$$
\frac{\phi_{n}-\phi_{D}}{\phi_{D}}
$$

in RRGE No. 2 for the depth interval $1392 \mathrm{~m}$ (4568 ft) to $1509 \mathrm{~m}$ (4952 ft) may indicate zones of increased fracturing within the sandstone. A problem with this plot is that $\phi_{D}$ and/or $\phi_{n} \infty$; therefore, the cross plot must be revamped to attempt to compensate for this problem (Fig. 22).

VI. SUMMARY AND CONCLUSIONS

The log responses for complex rocks, including tuffaceous sediments, metamorphics, and quartz monzonite are more complicated than those in: typical sedimentary rocks. Cross-plotting techniques clearly delineate the complex rock types and zones of increased alteration and increased fracturing.

The cross plots indicate that the quartz monzonite, schist, and siltstone are fractured in RRGE No. 1. In RRGE No. 2, the quartzite, quartz monzonite, and sandstone appear fractured. In both wells, the fracturing may have enhanced the intergranular porosity in the siltstone and sandstone and, hence, improved production. The quartzite appears altered in RRGE No. 1, whereas in RRGE No. 2 the quartzite and schist are more altered in the quartzite than in the schist. In RRGE No. 4, fracturing must be minimal, and the schist and quartzite appear to be altered. The lack of fracturing in the schist, quartzite, and siltstone, and the partial sealing of the siltstone with alteration products contributes to the lack of production from RRGE No. 4.

The production in the Raft River geothermal system comes from several formations near the sediment-basement complex. Fracturing may enhance the normal production from the intergranular porosity. Alteration products could be reducing effective porosity in some of the units. Multiple stages of faulting (older thrusts, followed by younger normal faults) may have controlled the distribution of faulting. 


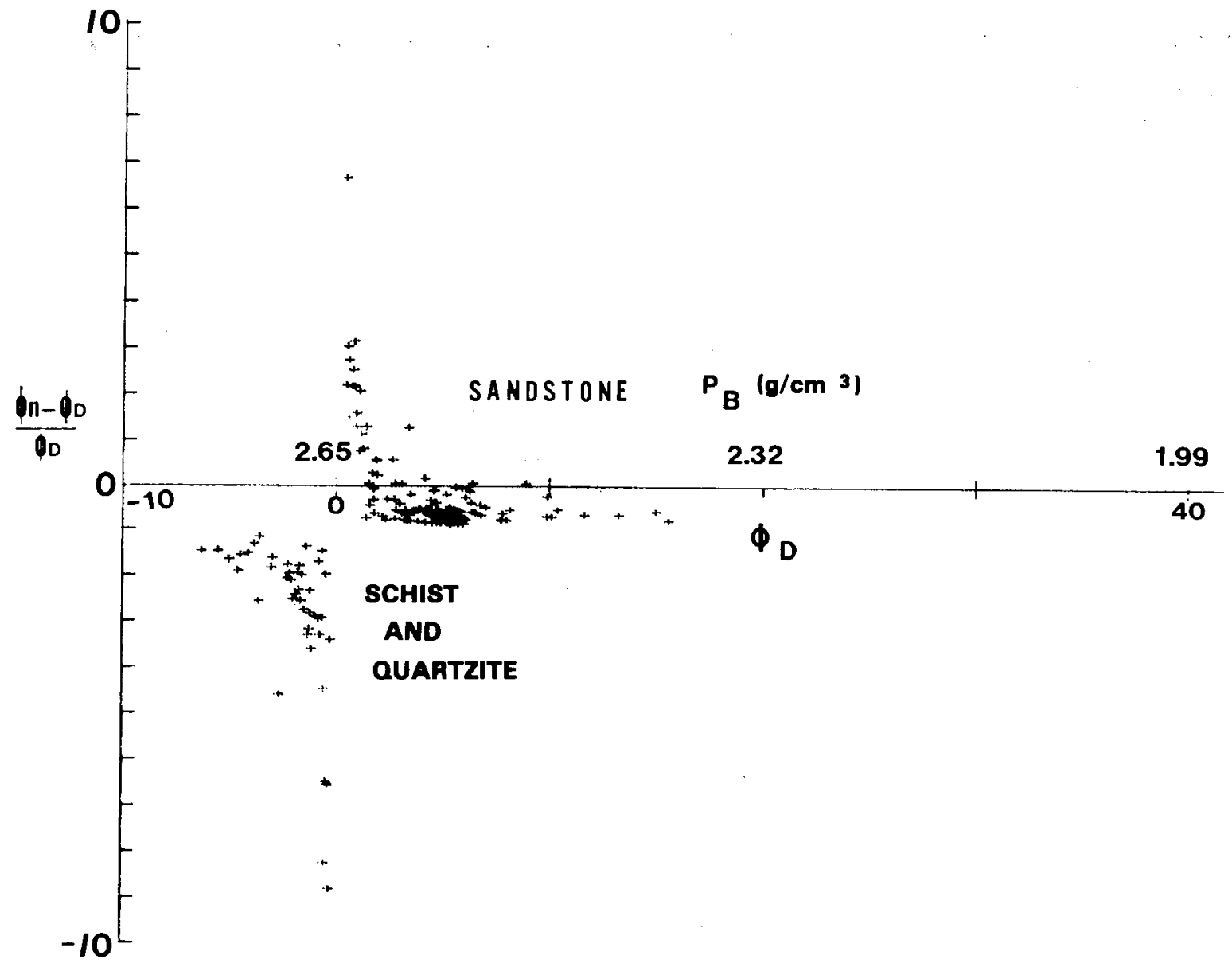

Fig. 22. Plot of $\frac{\phi_{n}-\phi_{D}}{\phi_{D}}$ vs $\phi_{D}$ (ss) for the depth interval $1392 \mathrm{~m}$ (4568 ft) to $1509 \mathrm{~m}$ (4952 ft) in RRGE No. 2 . 
Careful cross plotting of data from all of the wells at Raft River should contribute to better understanding of the nature of the reservoir and a further refined interpretation technique. A particular benefit would be a better appreciation of the effects of alteration products on $10 g$ responses, and perhaps a quantitative procedure for analyzing alteration. The porosity logs provide the most useful data and should be run in subsequent wells in addition to a multiarmed caliper and a spectral tool. 
REFERENCES

H. D. Ackerman, 1975, "Seismic Refraction Study in the Raft River Geothermal Area, Idaho" (abstract), Geophysics, Vol. 41, No. 2, p. 336.

J. K. Applegate and P. R. Donaldson, 1977, "Characteristics of Selected Geothermal Systems in Idaho in The Earth's Crust," Am. Geophys. Union Monograph 20, pp. 676-692.

H. R. Covington, 1977, "Deep Drilling Data Raft River Geothermal Area, Idaho, Raft River Geothermal Exploration Well No. 2," USGS Open-file report 77-243.

W. E. Glenn and J. B. Hulen, 1979, "A Study of Well Logs from Roosevelt Hot Springs KGRA, Utah," Transactions of the 20 th Ann. Soc. Prof. Well Log Analysts Mtg., Tulsa, Oklahoma, paper ZZ.

D. R. Mabey, A. A. R. Zohdy, D. B. Hoover, D. B. Jackson, and J. O'Donnell, 1975, "Geophysical Studies of a Geothermal Area in the Southern Raft River Valley, Idaho," (abstract), Geol. Soc., Am. Abstr. Program, Vol. 7 , No. 5 , p. 624 .

D. R. Mabey, D. B. Hoover, J. E. O'Donnell, and G. W. Wilson, 1978, "Reconnaissance Geophysical Studies of the Geothermal System in Southern Raft River Valley, Idaho," Geophysics, Vol. 43, No. 7, pp. 1470-1484.

C. R. Nichols and J. K. Applegate, 1974, "Geologic and Geophysical Aspects of Site Selection for a Geothermal Demonstration Project, Raft River, Idaho," Idaho Geothermal R \& D Project Report for Dec. 16, 1973 to Mar. 15, 1974, report ANCR-1155, pp. 24-34, Atomic Energy Commission, Idaho Falls, Idaho.

P. L. Williams, K. L. Pierce, D. H. McIntyre, H. R. Covington, and P. W. Schmidt, 1975, "Geologic Setting of the Raft River Geothermal Area, Idaho," (abstract), Geol. Soc. Am. Abstr. Programs, Vol. 7, No. 5, p. 652 .

A. A. R. Zohdy, D. B. Jackson, and R. J. Bisdorg, 1975, "Exploring the Raft River Geothermal Area, Idaho," (abstract), Geophysics, Vol. 41, No. 2, p. 382 . 